\title{
LEVEL II SCOUR ANALYSIS FOR BRIDGE 39 (BETHTH00060039) on TOWN HIGHWAY 6, crossing the SECOND BRANCH WHITE RIVER, BETHEL, VERMONT
}

Open-File Report 98-060

Prepared in cooperation with

VERMONT AGENCY OF TRANSPORTATION

and

FEDERAL HIGHWAY ADMINISTRATION

U.S. Department of the Interior

U.S. Geological Survev

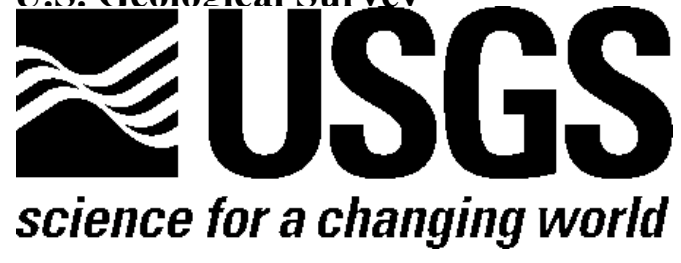




\section{LEVEL II SCOUR ANALYSIS FOR BRIDGE 39 (BETHTH00060039) on TOWN HIGHWAY 6, crossing the SECOND BRANCH WHITE RIVER, BETHEL, VERMONT}

By LORA K. STRIKER AND MICHAEL A. IVANOFF

U.S. Geological Survey Open-File Report 98-060

Prepared in cooperation with

VERMONT AGENCY OF TRANSPORTATION and

FEDERAL HIGHWAY ADMINISTRATION 


\title{
U.S. DEPARTMENT OF THE INTERIOR BRUCE BABBITT, Secretary
}

\author{
U.S. GEOLOGICAL SURVEY
}

Thomas J. Casadevall, Acting Director

For additional information write to:

District Chief

U.S. Geological Survey 361 Commerce Way

Pembroke, NH 03275-376
Copies of this report may be purchased from:

U.S. Geological Survey

Branch of Information Services

Open-File Reports Unit

Box 25286

Denver, CO 80225-0286 


\section{CONTENTS}

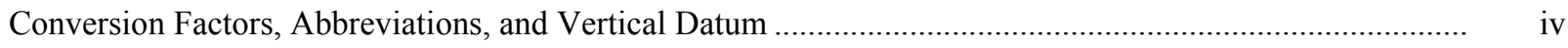

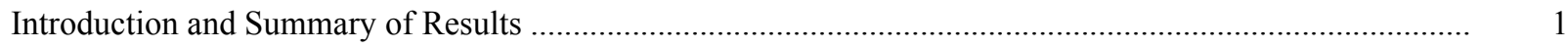

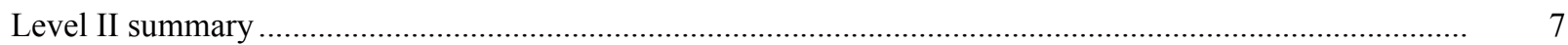

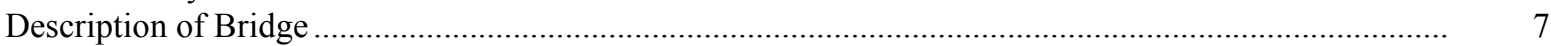

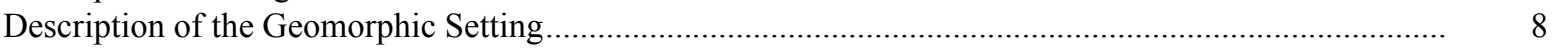

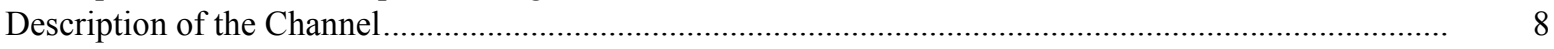

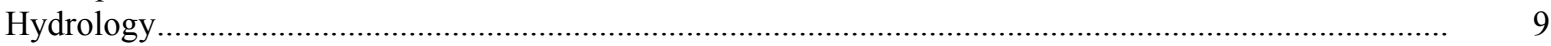

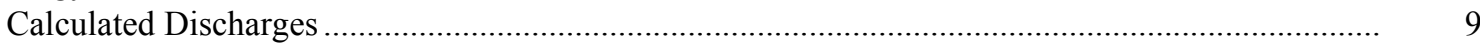

Description of the Water-Surface Profile Model (WSPRO) Analysis .................................................... 10

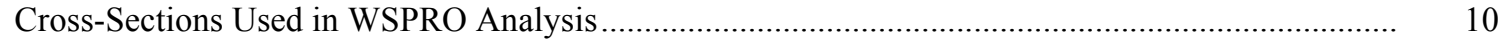

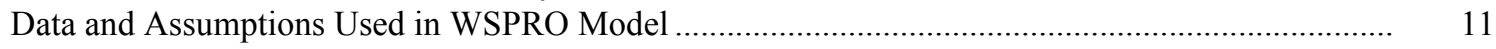

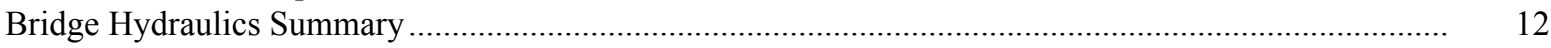

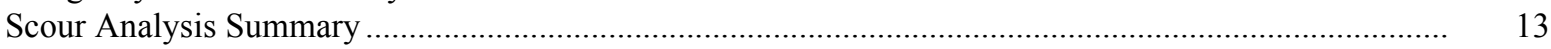

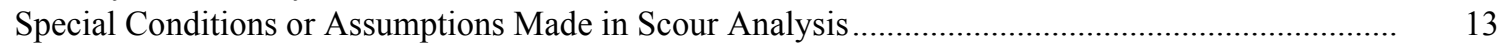

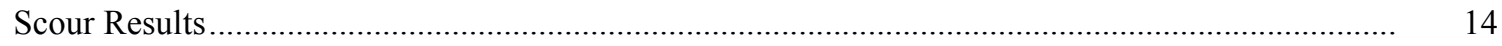

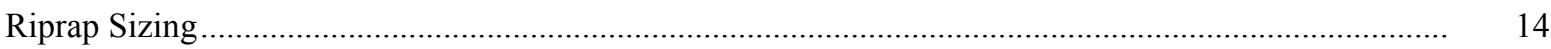

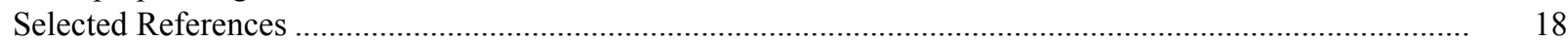

Appendices:

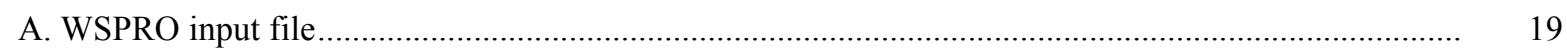

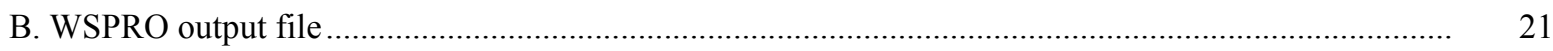

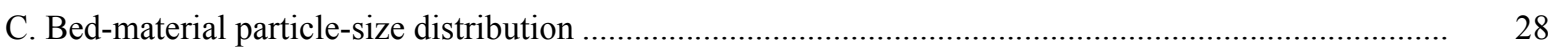

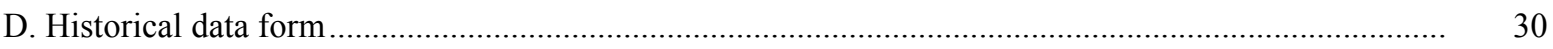

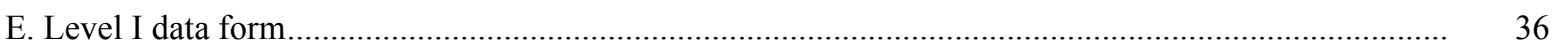

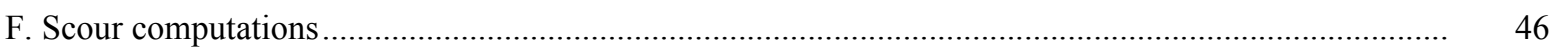

\section{FIGURES}

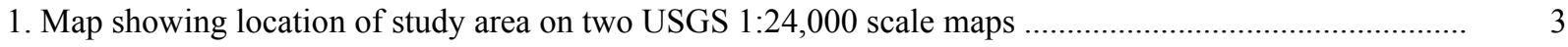

2. Map showing location of study area on Vermont Agency of Transportation town

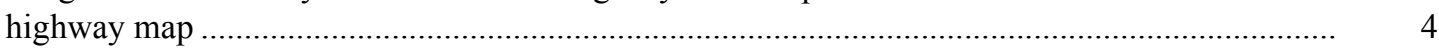

3. Structure BETHTH00060039 viewed from upstream (July 11, 1996) ................................................. 5

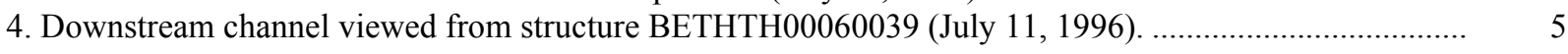

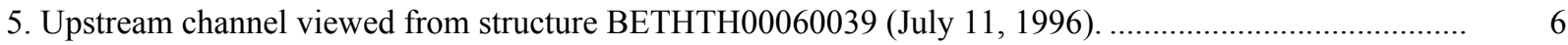

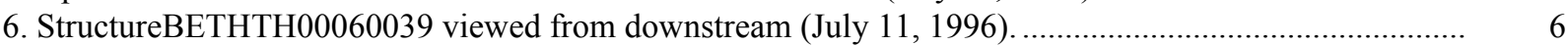

7. Water-surface profiles for the 100- and 500-year discharges at structure

BETHTH00060039 on Town Highway 6, crossing the Second Branch White River

Bethel, Vermont.

8. Scour elevations for the 100- and 500-year discharges at structure

BETHTH00060039 on Town Highway 6, crossing the Second Branch White River

Bethel, Vermont.

\section{TABLES}

1. Remaining footing/pile depth at abutments for the 100-year discharge at structure

BETHTH00060039 on Town Highway 6, crossing the Second Branch White River

Bethel, Vermont.

2. Remaining footing/pile depth at abutments for the 500-year discharge at structure

BETHTH00060039 on Town Highway 6, crossing the Second Branch White River

Bethel, Vermont. 


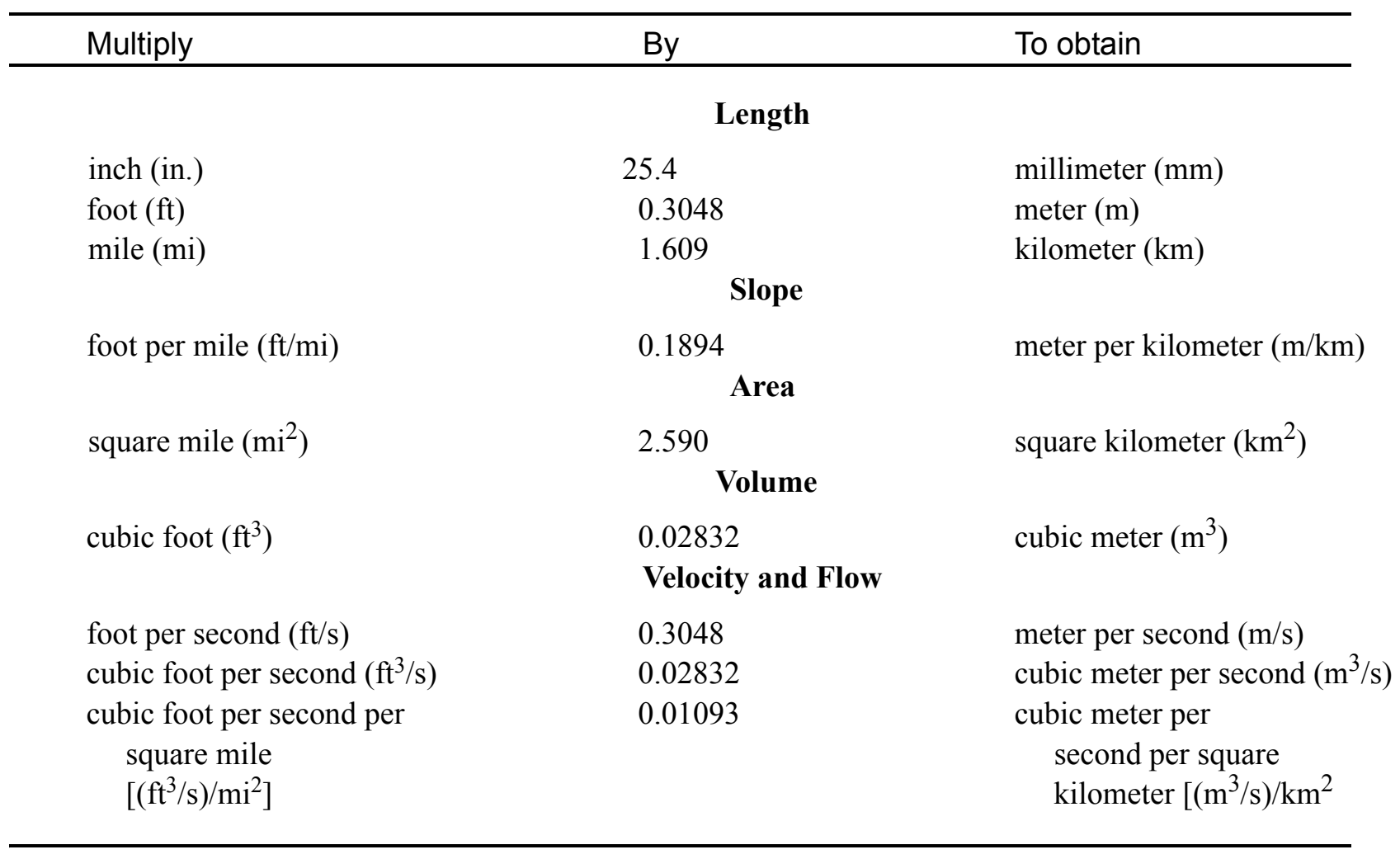

\section{OTHER ABBREVIATIONS}

$\begin{array}{lrlr}\mathrm{BF} & \begin{array}{r}\text { bank full } \\ \mathrm{cfs}\end{array} & \text { LWW } & \text { left wingwall } \\ \mathrm{D}_{50} & \text { cubic feet per second } & \text { Max } & \text { maximum } \\ \mathrm{DS} & \text { median diameter of bed material } & \text { MC } & \text { main channel } \\ \mathrm{elev} & \text { downstream } & \text { RAB } & \text { right abutment } \\ \mathrm{f} / \mathrm{p} & \text { elevation } & \text { RABUT } & \text { face of right abutment } \\ \mathrm{ft} & \text { flood plain } & \text { RB } & \text { right bank } \\ \mathrm{ft} / \mathrm{ft} & \text { square feet } & \text { ROB } & \text { right overbank } \\ \mathrm{FEMA} & \text { feet per foot } & \text { RWW } & \text { right wingwall } \\ \mathrm{FHWA} & \text { Federal Emergency Management Agency } & \text { TH } & \text { town highway } \\ \text { JCT } & \text { Federal Highway Administration } & \text { UB } & \text { under bridge } \\ \text { LAB } & \text { junction } & \text { US } & \text { upstream } \\ \text { LABUT } & \text { left abutment } & \text { USGS } & \text { United States Geological Survey } \\ \text { LB } & \text { face of left abutment } & \text { VTAOT } & \text { Vermont Agency of Transportation } \\ \text { LOB } & \text { left bank } & \text { WSPRO } & \text { water-surface profile model } \\ & \text { left overbank } & \text { yr } & \text { year }\end{array}$

In this report, the words "right" and "left" refer to directions that would be reported by an observer facing downstream. Sea level: In this report, "sea level" refers to the National Geodetic Vertical Datum of 1929-- a geodetic datum derived from a general adjustment of the first-order level nets of the United States and Canada, formerly called Sea Level Datum of 1929. 


\title{
LEVEL II SCOUR ANALYSIS FOR BRIDGE 39 (BETHTH00060039) ON TOWN HIGHWAY 6, CROSSING THE SECOND BRANCH WHITE RIVER, BETHEL, VERMONT
}

\author{
By Lora K. Striker and Michael A. Ivanoff
}

\section{INTRODUCTION AND SUMMARY OF RESULTS}

This report provides the results of a detailed Level II analysis of scour potential at structure BETHTH00060039 on Town Highway 6 crossing the Second Branch White River, Bethel, Vermont (figures 1-8). A Level II study is a basic engineering analysis of the site, including a quantitative analysis of stream stability and scour (FHWA, 1993). Results of a Level I scour investigation also are included in appendix $\mathrm{E}$ of this report. A Level I investigation provides a qualitative geomorphic characterization of the study site. Information on the bridge, gleaned from VTAOT files, was compiled prior to conducting Level I and Level II analyses and is found in appendix D.

The site is in the Green Mountain section of the New England physiographic province in central Vermont. The 64.4- $\mathrm{mi}^{2}$ drainage area is in a predominantly rural and forested basin. In the vicinity of the study site, the surface cover is predominantly shrub and brushland.

In the study area, the Second Branch White River has a meandering channel with a slope of approximately $0.003 \mathrm{ft} / \mathrm{ft}$, an average channel top width of $73 \mathrm{ft}$ and an average bank height of $6 \mathrm{ft}$. The channel bed material ranges from sand to cobble with a median grain size $\left(\mathrm{D}_{50}\right)$ of $1.26 \mathrm{~mm}(0.00412 \mathrm{ft})$. The geomorphic assessment at the time of the Level I and Level II site visit on July 11, 1996, indicated that the reach was stable.

The Town Highway 6 crossing of the Second Branch White River is a 52-ft-long, two-lane bridge consisting of one 49 foot steel beam span (VTAOT, written communication, August $24,1994)$. The opening length of the structure parallel to the bridge face is $46.6 \mathrm{ft}$. The bridge is supported by vertical, concrete abutments. The channel is skewed approximately 20 degrees to the opening while the computed opening-skew-to-roadway is 5 degrees.

A scour hole $3.0 \mathrm{ft}$ deeper than the mean thalweg depth was observed along the left and right abutments during the Level I assessment. The only scour protection measure at the site was type- 2 stone fill (less than 36 inches diameter) along the right bank upstream and the left bank downstream. Additional details describing conditions at the site are included in the Level II Summary and appendices D and $\mathrm{E}$. 
Scour depths and recommended rock rip-rap sizes were computed using the general guidelines described in Hydraulic Engineering Circular 6 (Richardson and Davis, 1995) for the 100- and 500-year discharges. In addition, the incipient roadway-overtopping discharge was determined and analyzed as another potential worst-case scour scenario. Total scour at a highway crossing is comprised of three components: 1) long-term streambed degradation; 2) contraction scour (due to accelerated flow caused by a reduction in flow area at a bridge) and; 3) local scour (caused by accelerated flow around piers and abutments). Total scour is the sum of the three components. Equations are available to compute depths for contraction and local scour and a summary of the results of these computations follows.

Contraction scour for all modelled flows ranged from 5.1 to $10.3 \mathrm{ft}$. The worst-case contraction scour occurred at the incipient roadway-overtopping discharge, which was less than the 100-year discharge. Abutment scour ranged from 19.0 to $26.2 \mathrm{ft}$. The worst-case abutment scour occurred at the 500-year discharge at the left abutment and the 100-year discharge at the right abutment. Additional information on scour depths and depths to armoring are included in the section titled "Scour Results". Scoured-streambed elevations, based on the calculated scour depths, are presented in tables 1 and 2. A cross-section of the scour computed at the bridge is presented in figure 8. Scour depths were calculated assuming an infinite depth of erosive material and a homogeneous particle-size distribution.

It is generally accepted that the Froehlich equation (abutment scour) gives "excessively conservative estimates of scour depths" (Richardson and Davis, 1995, p. 47). Usually, computed scour depths are evaluated in combination with other information including (but not limited to) historical performance during flood events, the geomorphic stability assessment, existing scour protection measures, and the results of the hydraulic analyses. Therefore, scour depths adopted by VTAOT may differ from the computed values documented herein. 


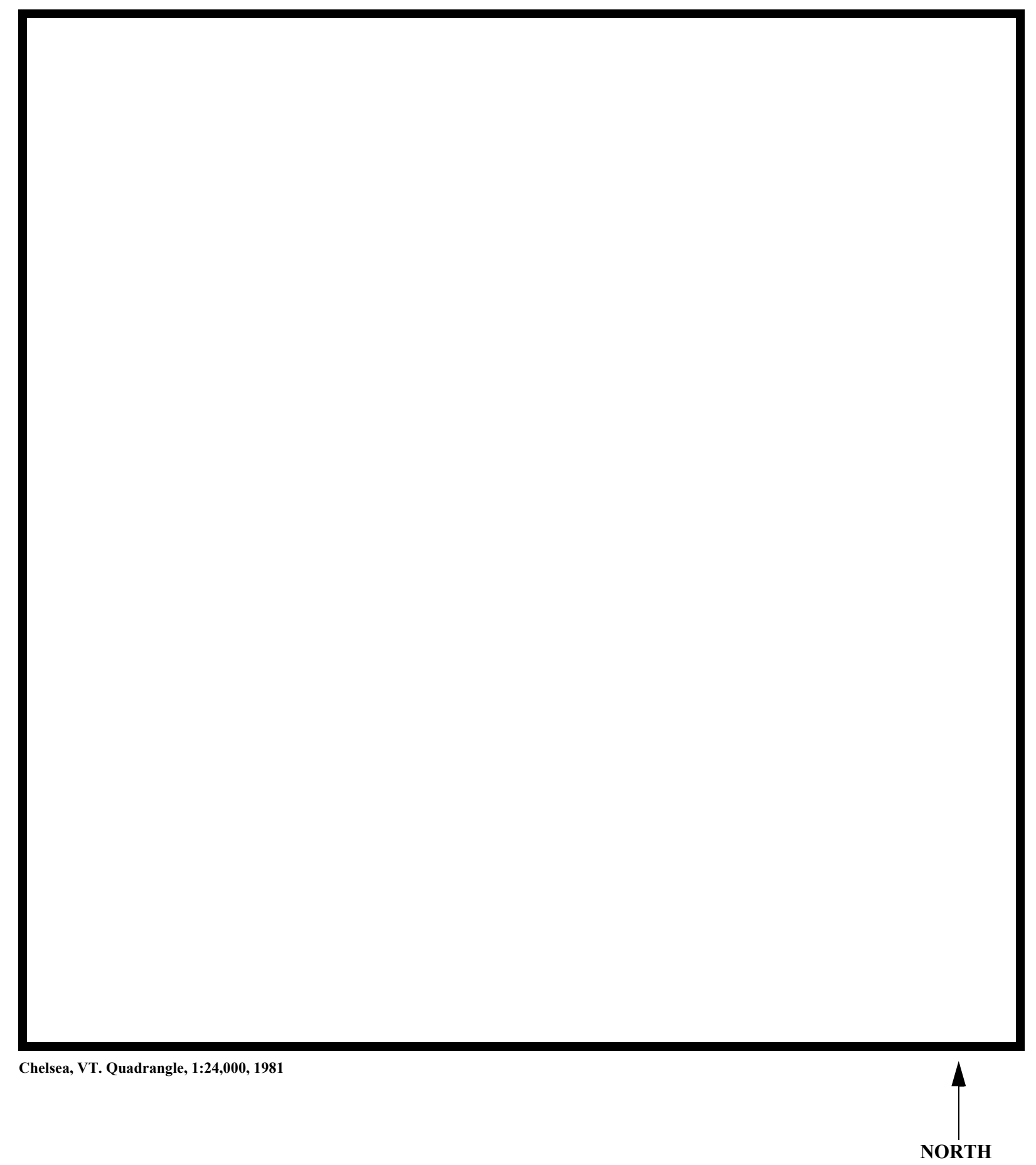

Figure 1. Location of study area on USGS 1:24,000 scale map. 
Figure 2. Location of study area on Vermont Agency of Transportation town highway map. 

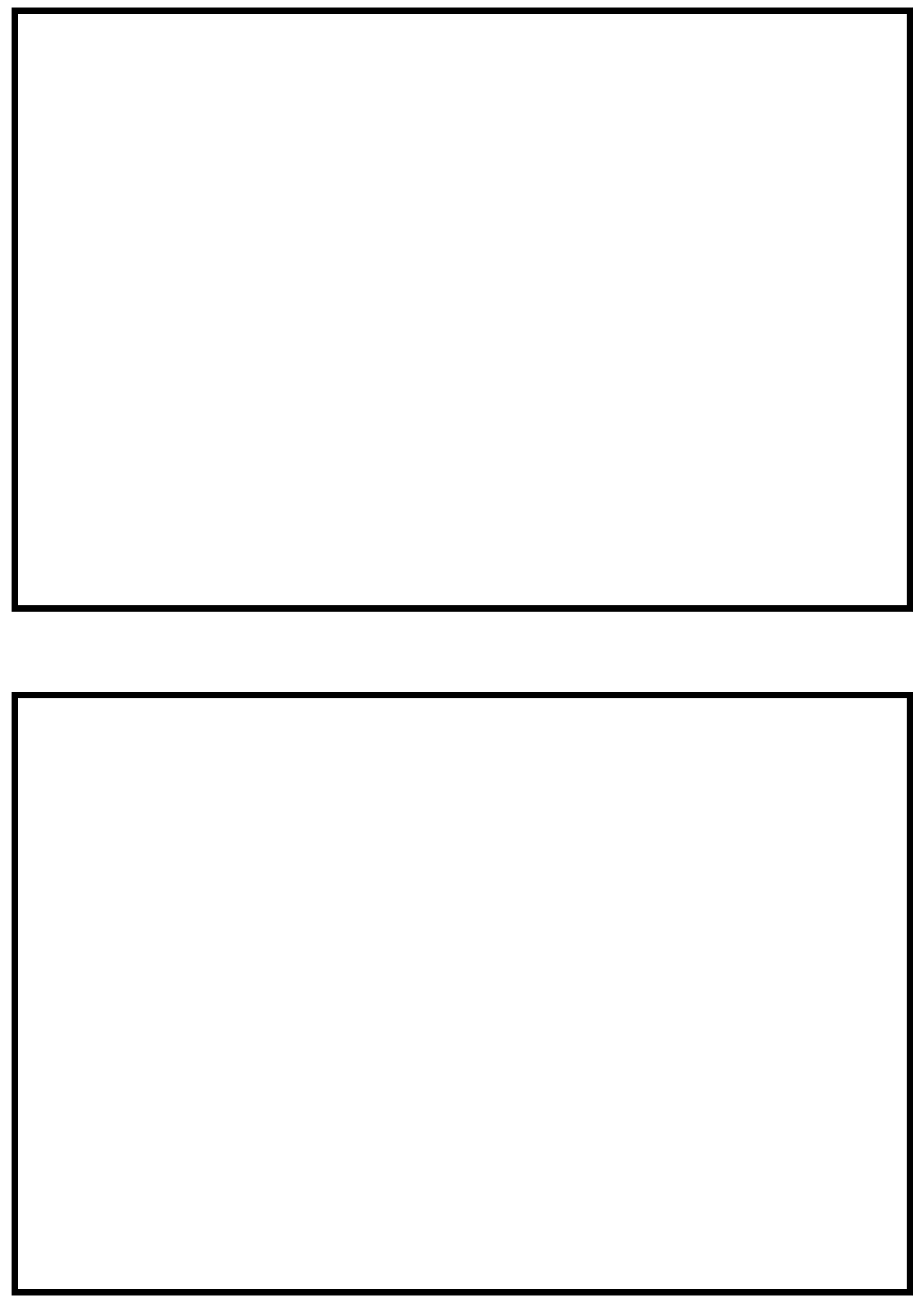

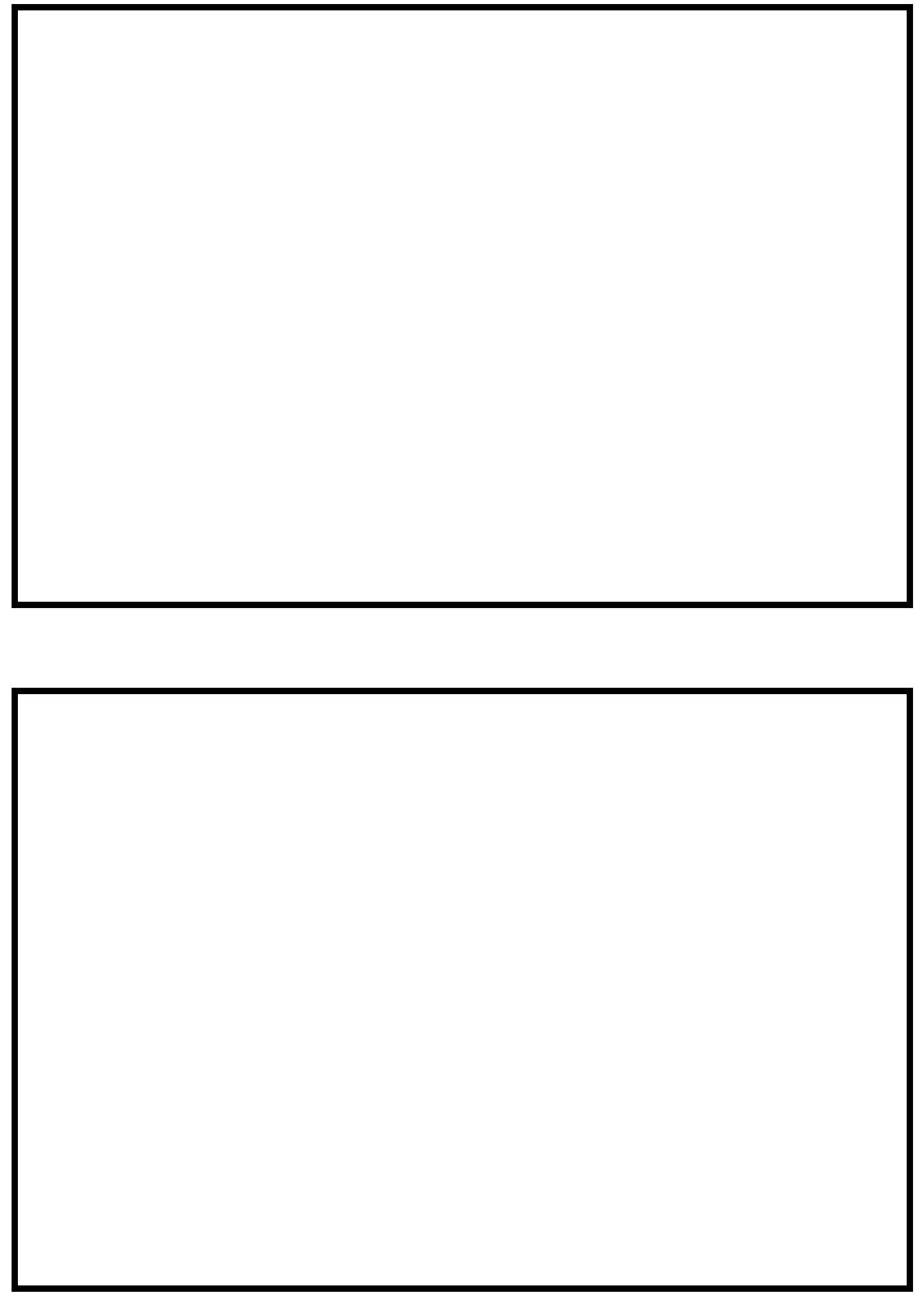


\section{LEVEL II SUMMARY}

\begin{tabular}{llllll} 
Structure Number & BETHTH00060039 & Stream & \multicolumn{3}{l}{ Second Branch White River } \\
& Woud & TH 6 & District & 4 \\
County & Windsor & Road
\end{tabular}

\section{Description of Bridge}

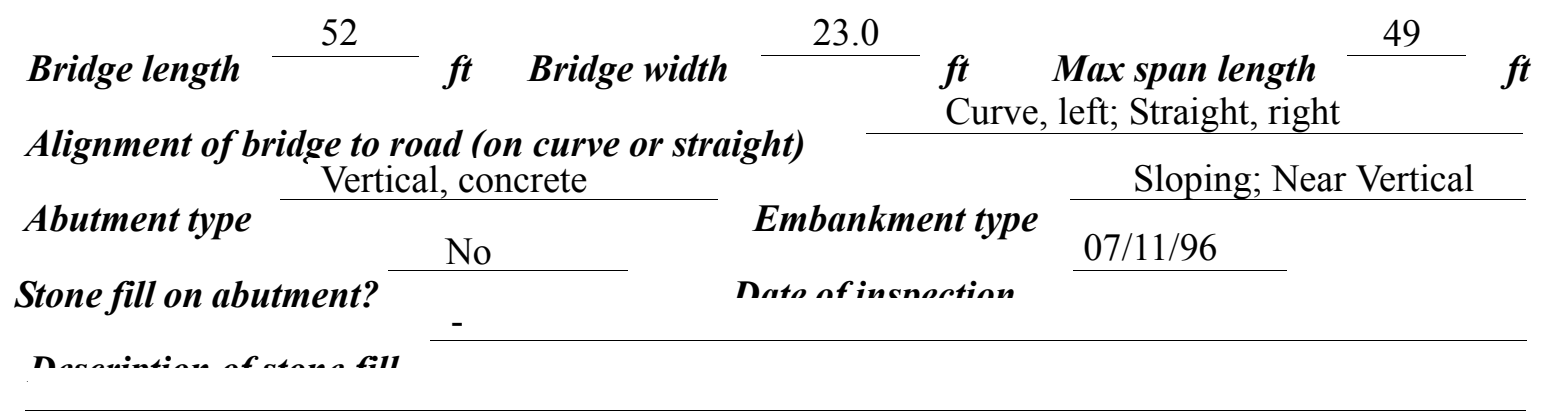

Abutments are concrete. There is a $3.0 \mathrm{ft}$ deep scour hole underneath the bridge that extends upstream and downstream. The left abutment footing is exposed $3.0 \mathrm{ft}$.

Yes

Is bridge skewed to flood flow according to Yes 'survey? Angle

20

There is a moderate channel bend in the upstream reach. The left abutment footing, is exposed in the location where the flow impacts the left abutment.

Debris accumulation on bridge at time of Level I or Level II site visit:

Date of insnortion $07 / 11 / 96$

Level I

\section{Percent of ahominal blocked nortzontatly}

0
Percent of allonel
blocked verticatty 0

Level II

Moderate. There are some dead tress along the banks upstream. In addition, the bridge is a constriction in the river.

Potential for debris

None as of 07/11/96.

Doscriho any, foaturos noar ar at tho hridos that mav, affoct flou, (includo ahsorvation dato) 


\section{Description of the Geomorphic Setting}

General topography The channel is located within a moderate relief valley with a narrow flood plain and steep valley walls on both sides.

Geomorphic conditions at bridge site: downstream (DS), upstream (US)

Date of inspection $\quad 07 / 11 / 96$

DS left: $\quad$ Steep channel bank to moderately sloping and irregular overbank

DS right: $\quad$ Moderately sloping channel bank and overbank

US left: $\quad$ Moderately sloping channel bank to narrow flood plain

US right: $\quad$ Steep channel bank and valley wall

\section{Description of the Channel}

\begin{tabular}{|c|c|c|c|}
\hline \multirow[b]{2}{*}{ Average top width } & 73 & \multirow[b]{2}{*}{ Average depth } & 6 \\
\hline & $\stackrel{f t}{\text { Silt/ Gravel }}$ & & Silt to Gravel \\
\hline \multicolumn{2}{|c|}{ Predominant bed material } & Bank material & Meandering with \\
\hline alluvial boundaries an & row point bars. & 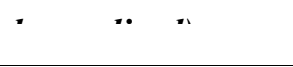 & \\
\hline
\end{tabular}

$07 / 11 / 96$

Vegetative col ${ }^{1}$ Trees and brush

DS left: $\quad$ Brush and trees

DS right: $\quad$ Brush

US left: $\quad$ Tall grasses and brush with a few trees, overbank area is marsh

US right: $\quad$ Yes

Do banks appear stable? -

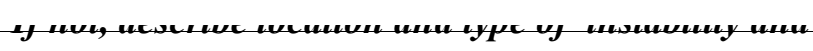

date of observatton.

None as of $07 / 11 / 96$.

Describe any obstructions in channel and date of observation. 


\title{
Hydrology
}

Drainage area $\quad 64.4 \boldsymbol{m i}^{2}$

Percentage of drainage area in physiographic provinces: (approximate)

Physiographic province/section

New England/Green Mountain
Percent of drainage area 100

\begin{abstract}
Is drainage area considered rural or urban?
Rural None.

urbanization:-

Describe any significant
\end{abstract}

Is there a USGS gage on the stream of interest?

No

USGS gage description

USGS gage number

Gage drainage area $\mathrm{mi}^{2}$

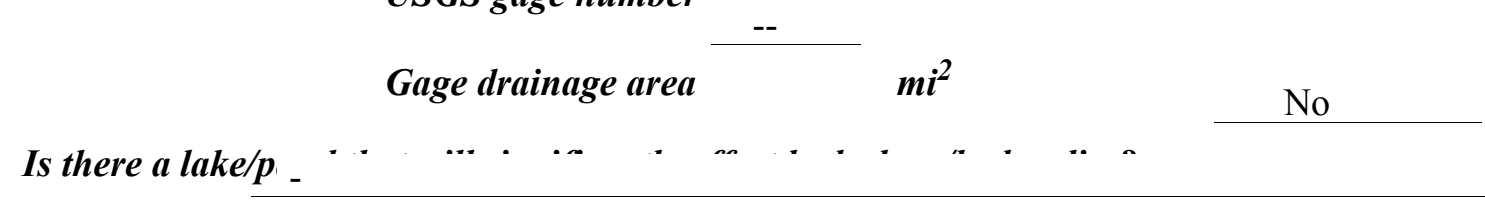

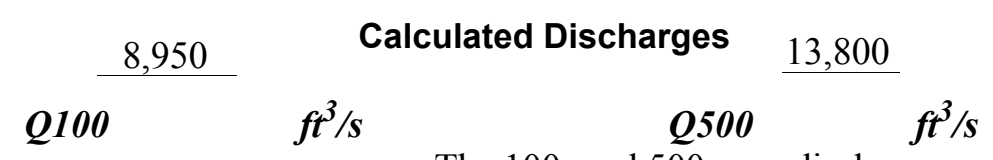

The 100- and 500-year discharges are based on a

drainage area relationship.[(64.4/46.0)exp 0.67] with bridge number 34 in Randolph. Bridge number 34 crosses the Second Branch of the White River upstream of this site and has flood frequency estimates available from the VTAOT database (VTAOT, written communication, May 1995). The drainage area above bridge number 34 is 46.0 square miles. The discharges are within a range defined by several other empirical methods (Benson, 1962; Johnson and Tasker, 1974; FHWA, 1983; Potter, 1957a\&b; Talbot, 1887). 


\section{Description of the Water-Surface Profile Model (WSPRO) Analysis}

Datum for WSPRO analysis (USGS survey, sea level, VTAOT plans)

USGS survey

Datum tie between USGS survey and VTAOT plans

None

Description of reference marks used to determine USGS datum. $\quad$ RM 1- center of chiseled square on top of the DS corner at the LB end of the US curb (elev. $500.63 \mathrm{ft}$, arbitrary survey

datum). RM 2- chiseled X on the top RB DS corner of concrete walkway (elev. $500.67 \mathrm{ft}$, arbitrary survey datum). RM 3 is a nail in telephone pole \#771/2- 771/1, 6' above ground, on LB US (elev.

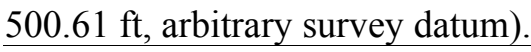

Crncs-Sertinnc Ilsed in WSPRO Analvcic

\begin{tabular}{cccl}
\hline${ }^{1}$ Cross-section & $\begin{array}{c}\text { Section } \\
\text { Reference } \\
\text { Distance } \\
\text { (SRD) in ft }\end{array}$ & $\begin{array}{c}{ }^{2} \text { Cross-section } \\
\text { development }\end{array}$ & \multicolumn{1}{c}{ Comments } \\
\hline EXT1 & -90 & 1 & Exit section (dam section) \\
EXITX & -30 & 1 & Exit section \\
FULLV & 0 & 2 & $\begin{array}{l}\text { Downstream Full-valley } \\
\text { section (Templated from } \\
\text { EXITX) }\end{array}$ \\
BRIDG & 0 & 1 & $\begin{array}{l}\text { Bridge section } \\
\text { Road Grade section }\end{array}$ \\
RDWAY & 13 & 1 & $\begin{array}{l}\text { Modelled Approach sec- } \\
\text { tion (Templated from } \\
\text { APTEM) }\end{array}$ \\
APTEM & 73 & 2 & $\begin{array}{l}\text { Approach section as sur- } \\
\text { veyed (Used as a tem- } \\
\text { plate) }\end{array}$ \\
\hline
\end{tabular}

${ }^{1}$ For location of cross-sections see plan-view sketch included with Level I field form, Appendix E. For more detail on how cross-sections were developed see WSPRO input file. 


\section{Data and Assumptions Used in WSPRO Model}

Hydraulic analyses of the reach were done by use of the Federal Highway Administration's WSPRO step-backwater computer program (Shearman and others, 1986, and Shearman, 1990). The analyses reported herein reflect conditions existing at the site at the time of the study. Furthermore, in the development of the model it was necessary to assume no accumulation of debris or ice at the site. Results of the hydraulic model are presented in the Bridge Hydraulic Summary, Appendix B, and figure 7.

Channel roughness factors (Manning's " $n$ ") used in the hydraulic model were estimated using field inspections at each cross section following the general guidelines described by Arcement and Schneider (1989). Final adjustments to the values were made during the modelling of the reach. Channel " $n$ " values for the reach ranged from 0.035 to 0.045 and overbank " $n$ " values ranged from 0.060 to 0.086 .

Critical depth at the exit section (EXT1) was assumed as the starting water surface for the discharges modelled. The EXT1 section was surveyed across the crest of the dam located approximately $90 \mathrm{ft}$ downstream of this site. The water surface profile from the Flood Insurance Study (FIS) for the town of Bethel shows that the flow may submerge the crest of the dam for the discharges modelled (Federal Emergency Management Agency, 1991). Thus, the actual starting water surface may be slightly above critical depth.

The surveyed approach section (APTEM) was moved without a bed slope correction to establish the modelled approach section (APPRO) one bridge length upstream of the upstream face as recommended by Shearman and others (1986). This location provides a consistent method for determining scour variables. 


\section{Bridge Hydraulics Summary}

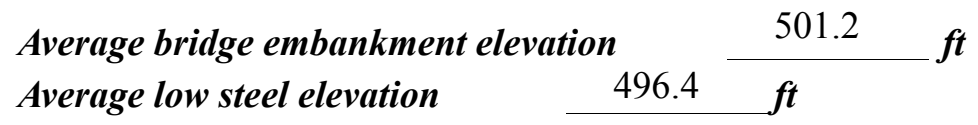

$$
\text { 100-year discharge } \quad 8,950 \quad \mathrm{ft}^{3} / \mathrm{s}
$$

Water-surface elevation in bridge opening $\quad 496.4 \quad f t$

Road overtopping? ___ Yes Discharge over road _ـ 2,430 $\boldsymbol{f t}^{3} / \mathrm{s}$

\begin{tabular}{llc} 
Area of flow in bridge opening & $542 \quad \boldsymbol{f t}^{2}$ \\
\cline { 2 - 2 } Average velocity in bridge opening & 12.0 & $\mathrm{ft} / \mathrm{s}$
\end{tabular}

$\begin{array}{llll}\text { Maximum WSPRO tube velocity at bridge } & 14.8 \mathrm{ft} / \mathrm{s}\end{array}$

Water-surface elevation at Approach section with bridge $\quad 501.0$

Water-surface elevation at Approach section without bridge $\quad 498.7$

Amount of backwater caused by bridge $\quad 2.3$ it

500-year discharge $\quad 13,800 \quad \mathrm{ft}^{3} / \mathrm{s}$

Water-surface elevation in bridge opening $\quad 496.4 \mathrm{ft}$

Road overtopping? ___ Yes Discharge over road _ $\quad 7,000, \mathrm{it}^{3} / \mathrm{s}$

Area of flow in bridge opening $\quad 542 \quad \mathrm{ft}^{2}$

Average velocity in bridge opening $12.6 \mathrm{ft} / \mathrm{s}$

Maximum WSPRO tube velocity at bridge 15.5 's

Water-surface elevation at Approach section with bridge

Water-surface elevation at Approach section without bridge

Amount of backwater caused by bridge $\quad 2.4$.t

502.5

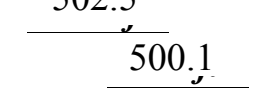

Incipient overtopping discharge $\quad 5,440 \quad \mathrm{ft}^{3} / \mathrm{s}$

Water-surface elevation in bridge opening $496.4 \quad t$

Area of flow in bridge opening $\quad 542 \quad \mathrm{ft}^{2}$

Average velocity in bridge opening $\quad 10.0 \quad \mathrm{ft} / \mathrm{s}$

Maximum WSPRO tube velocity at bridge $\quad 14.6 \mathrm{ft} / \mathrm{s}$

Water-surface elevation at Approach section with bridge

Water-surface elevation at Approach section without bridge

498.7

Amount of backwater caused by bridge $\quad 1.7_{\text {, t }}$ 


\section{Scour Analysis Summary}

\section{Special Conditions or Assumptions Made in Scour Analysis}

Scour depths were computed using the general guidelines described in Hydraulic Engineering Circular 6 (Richardson and Davis, 1995). Scour depths were calculated assuming an infinite depth of erosive material and a homogeneous particle-size distribution. The results of the scour analysis for the 100- and 500-year discharges are shown in tables 1 and 2 and the scour depths are shown graphically in figure 8.

Contraction scour for the 100-year, 500-year, and incipient roadway-overtopping discharges was computed by use of the Laursen live-bed contraction scour equation (Richardson and Davis, 1995, p. 30, equation 17). At this site, each modeled discharge resulted in submerged orifice flow. The Chang equation for pressure flow scour (Richardson and Davis, 1995, p. 145-146) was derived solely with data for clear-water scour. Therefore, it is not currently understood how well it would predict in live-bed conditions. Although pressure flow conditions exist for the modeled discharges, the reported scour depths are those computed by use of Laursen's live-bed contraction scour equation. For comparison, estimates of contraction scour were computed by use of the Chang equation and the Umbrell pressure-flow equation (Richardson and Davis, 1995, p. 144) for each discharge. These contraction scour results are provided in appendix $\mathrm{F}$.

Abutment scour was computed by use of the Froehlich equation (Richardson and Davis, 1995, p. 48, equation 28). Variables for the Froehlich equation include the Froude number of the flow approaching the embankments, the length of the embankment blocking flow, and the depth of flow approaching the embankment less any roadway overtopping. 


\section{Scour Results}

100-yr discharge 500-yr discharge

Contraction scour:

(Scour depths in feet)

Main channel

Live-bed scour
Clear-water scour
Depth to armoring
bank
erbank

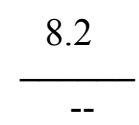

$\mathrm{N} / \mathrm{A}^{-}$

Left overbank

Right overbank

Local scour:

Abutment scour

Left abutment

Right abutment

Pier scour

Pier 1

Pier 2

Pier 3
Abutments:

\section{Left abutment}

Right abutment

Piers:

Pier 1

Pier 2
Incipient overtopping discharge 


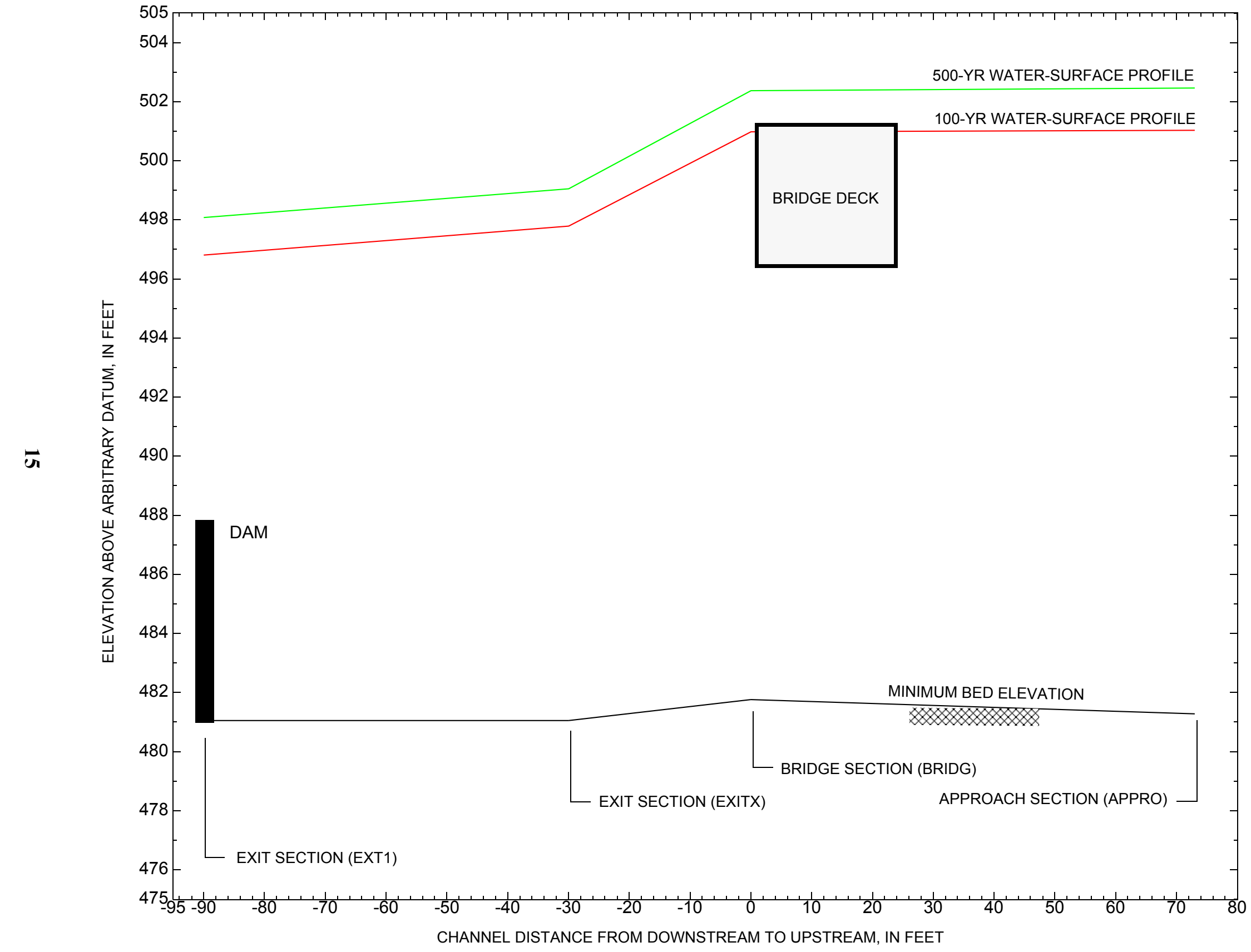

Figure 7. Water-surface profiles for the 100- and 500-year discharges at structure BETHTH00060039 on Town Highway 6, crossing the Second Branch White River, Bethel, Vermont. 


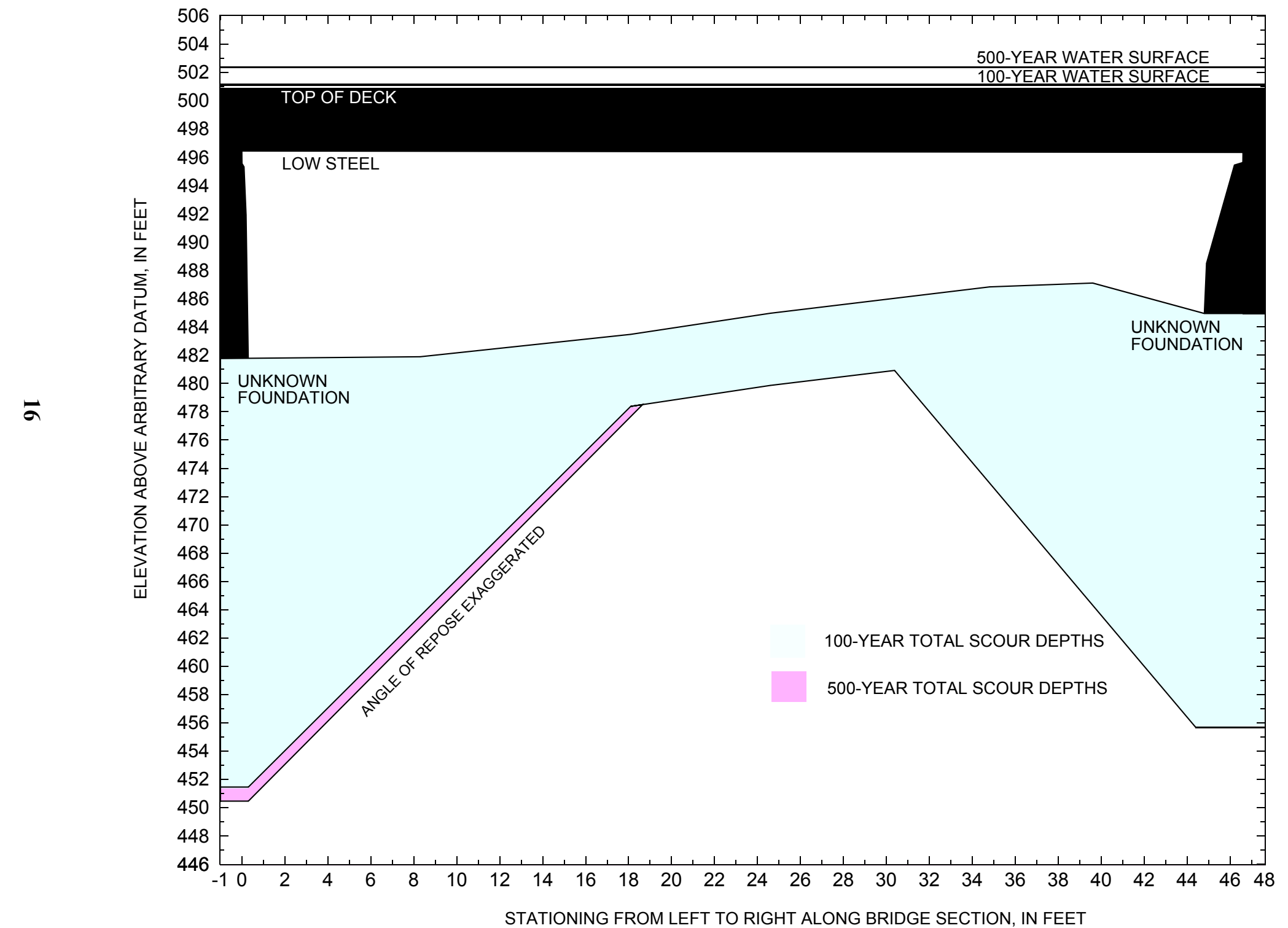

Figure 8. Scour elevations for the 100- and 500-year discharges at structure BETHTH00060039 on Town Highway 6, crossing the Second Branch White River, Bethel, Vermont. 
Table 1. Remaining footing/pile depth at abutments for the 100-year discharge at structure BETHTH00060039 on Town Highway 6, crossing the Second Branch White River, Bethel, Vermont.

[VTAOT, Vermont Agency of Transportation; --,no data]

\begin{tabular}{|c|c|c|c|c|c|c|c|c|c|c|c|}
\hline Description & Station $^{1}$ & $\begin{array}{l}\text { VTAOT } \\
\text { minimum } \\
\text { low-chord } \\
\text { elevation } \\
\text { (ft) }\end{array}$ & $\begin{array}{l}\text { Surveyed } \\
\text { minimum } \\
\text { low-chord } \\
\text { elevation }{ }^{2} \\
\text { (ft) }\end{array}$ & $\begin{array}{c}\text { Bottom of } \\
\text { footing } \\
\text { elevation } \\
\text { (ft) }\end{array}$ & $\begin{array}{l}\text { Channel } \\
\text { elevation at } \\
\text { abutment/ } \\
\text { pier }^{2} \\
\text { (ft) }\end{array}$ & $\begin{array}{l}\text { Contraction } \\
\text { scour depth } \\
\text { (ft) }\end{array}$ & $\begin{array}{l}\text { Abutment } \\
\text { scour } \\
\text { depth (ft) }\end{array}$ & $\begin{array}{l}\text { Pier } \\
\text { scour } \\
\text { depth } \\
\text { (ft) }\end{array}$ & $\begin{array}{l}\text { Depth of } \\
\text { total scour } \\
\text { (ft) }\end{array}$ & $\begin{array}{c}\text { Elevation of } \\
\text { scour }^{2} \\
\text { (ft) }\end{array}$ & $\begin{array}{c}\text { Remaining } \\
\text { footing/pile } \\
\text { depth } \\
\text { (ft) }\end{array}$ \\
\hline \multicolumn{12}{|c|}{100 -year discharge is 8,950 cubic-ft per second } \\
\hline Left abutment & 0.0 & -- & 496.4 & -- & 481.8 & 8.2 & 22.1 & -- & 30.3 & 451.5 & -- \\
\hline Right abutment & 46.6 & -- & 496.4 & -- & 485.0 & 8.2 & 20.9 & -- & 29.1 & 455.9 & -- \\
\hline
\end{tabular}

1.Measured along the face of the most constricting side of the bridge.

2.Arbitrary datum for this study.

Table 2. Remaining footing/pile depth at abutments for the 500-year discharge at structure BETHTH00060039 on Town Highway 6, crossing the Second Branch White River, Bethel, Vermont.

[VTAOT, Vermont Agency of Transportation; --, no data]

\begin{tabular}{|c|c|c|c|c|c|c|c|c|c|c|c|}
\hline Description & Station $^{1}$ & $\begin{array}{l}\text { VTAOT } \\
\text { minimum } \\
\text { low-chord } \\
\text { elevation } \\
\text { (ft) }\end{array}$ & $\begin{array}{l}\text { Surveyed } \\
\text { minimum } \\
\text { low-chord } \\
\text { elevation }{ }^{2} \\
\text { (ft) }\end{array}$ & $\begin{array}{c}\text { Bottom of } \\
\text { footing } \\
\text { elevation } \\
\text { (ft) }\end{array}$ & $\begin{array}{l}\text { Channel } \\
\text { elevation at } \\
\text { abutment/ } \\
\text { pier }^{2} \\
\text { (ft) }\end{array}$ & $\begin{array}{l}\text { Contraction } \\
\text { scour depth } \\
\text { (ft) }\end{array}$ & $\begin{array}{l}\text { Abutment } \\
\text { scour } \\
\text { depth (ft) }\end{array}$ & $\begin{array}{l}\text { Pier } \\
\text { scour } \\
\text { depth } \\
\text { (ft) }\end{array}$ & $\begin{array}{l}\text { Depth of } \\
\text { total scour } \\
\text { (ft) }\end{array}$ & $\begin{array}{c}\text { Elevation of } \\
\text { scour }^{2} \\
\text { (ft) }\end{array}$ & $\begin{array}{c}\text { Remaining } \\
\text { footing/pile } \\
\text { depth } \\
\text { (ft) }\end{array}$ \\
\hline \multicolumn{12}{|c|}{500 -year discharge is 13,800 cubic- $\mathrm{ft}$ per second } \\
\hline Left abutment & 0.0 & -- & 496.4 & -- & 481.8 & 5.1 & 26.2 & -- & 31.3 & 450.5 & -- \\
\hline Right abutment & 46.6 & -- & 496.4 & -- & 485.0 & 5.1 & 20.6 & -- & 25.7 & 459.3 & -- \\
\hline
\end{tabular}

1.Measured along the face of the most constricting side of the bridge.

2.Arbitrary datum for this study. 


\section{SELECTED REFERENCES}

Arcement, G.J., Jr., and Schneider, V.R., 1989, Guide for selecting Manning's roughness coefficients for natural channels and flood plains:

U.S. Geological Survey Water-Supply Paper 2339, 38 p.

Barnes, H.H., Jr., 1967, Roughness characteristics of natural channels: U.S. Geological Survey Water-Supply Paper 649, 213 p.

Benson, M. A., 1962, Factors Influencing the Occurrence of Floods in a Humid Region of Diverse Terrain: U.S. Geological Survey WaterSupply Paper 1580-B, 64 p.

Brown, S.A. and Clyde, E.S., 1989, Design of riprap revetment: Federal Highway Administration Hydraulic Engineering Circular No. 11, Publication FHWA-IP-89-039, 156 p.

Federal Highway Administration, 1983, Runoff estimates for small watersheds and development of sound design: Federal Highway Administration Report FHWA-RD-77-158.

Federal Highway Administration, 1993, Stream Stability and Scour at Highway Bridges: Participant Workbook: Federal Highway Administration Report FHWA-HI-91-011.

Federal Emergency Management Agency, 1991, Flood Insurance Study, Town of Bethel, Windsor County, Vermont: Washington, D.C., August, 1991.

Froehlich, D.C., 1989, Local scour at bridge abutments in Ports, M.A., ed., Hydraulic Engineering--Proceedings of the 1989 National Conference on Hydraulic Engineering: New York, American Society of Civil Engineers, p. 13-6.

Hayes, D.C.,1993, Site selection and collection of bridge-scour data in Delaware, Maryland, and Virginia: U.S. Geological Survey WaterResources Investigation Report 93-4017, 23 p.

Interagency Advisory Committee on Water Data, 1982, Guidelines for determining flood flow frequency: U.S. Geological Survey, Bulletin 17B of the Hydrology Subcommittee, 190 p.

Johnson, C.G. and Tasker, G.D.,1974, Progress report on flood magnitude and frequency of Vermont streams: U.S. Geological Survey OpenFile Report 74-130, 37 p.

Lagasse, P.F., Schall, J.D., Johnson, F., Richardson, E.V., Chang, F., 1995, Stream Stability at Highway Structures: Federal Highway Administration Hydraulic Engineering Circular No. 20, Publication FHWA-IP-90-014, 144 p.

Laursen, E.M., 1960, Scour at bridge crossings: Journal of the Hydraulics Division, American Society of Civil Engineers, v. 86, no. HY2, p. 39-53.

Potter, W. D., 1957a, Peak rates of runoff in the Adirondack, White Mountains, and Maine woods area, Bureau of Public Roads

Potter, W. D., 1957b, Peak rates of runoff in the New England Hill and Lowland area, Bureau of Public Roads

Richardson, E.V. and Davis, S.R., 1995, Evaluating scour at bridges: Federal Highway Administration Hydraulic Engineering Circular No. 18, Publication FHWA-IP-90-017, 204 p.

Richardson, E.V., Simons, D.B., and Julien, P.Y., 1990, Highways in the river environment: Federal Highway Administration Publication FHWA-HI-90-039.

Ritter, D.F., 1984, Process Geomorphology: W.C. Brown Co., Debuque, Iowa, 603 p.

Shearman, J.O., 1990, User's manual for WSPRO--a computer model for water surface profile computations: Federal Highway Administration Publication FHWA-IP-89-027, 67 p.

Shearman, J.O., Kirby, W.H., Schneider, V.R., and Flippo, H.N., 1986, Bridge waterways analysis model; research report: Federal Highway Administration Publication FHWA-RD-86-108, 112 p.

Talbot, A.N., 1887, The determination of water-way for bridges and culverts.

U.S. Geological Survey, 1981, South Royalton and Randolph Center, Vermont 7.5 Minute Series quadrangle map: U.S. Geological Survey Topographic Maps, Scale 1:24,000. 


\section{APPENDIX A: \\ WSPRO INPUT FILE}


WSPRO INPUT FILE

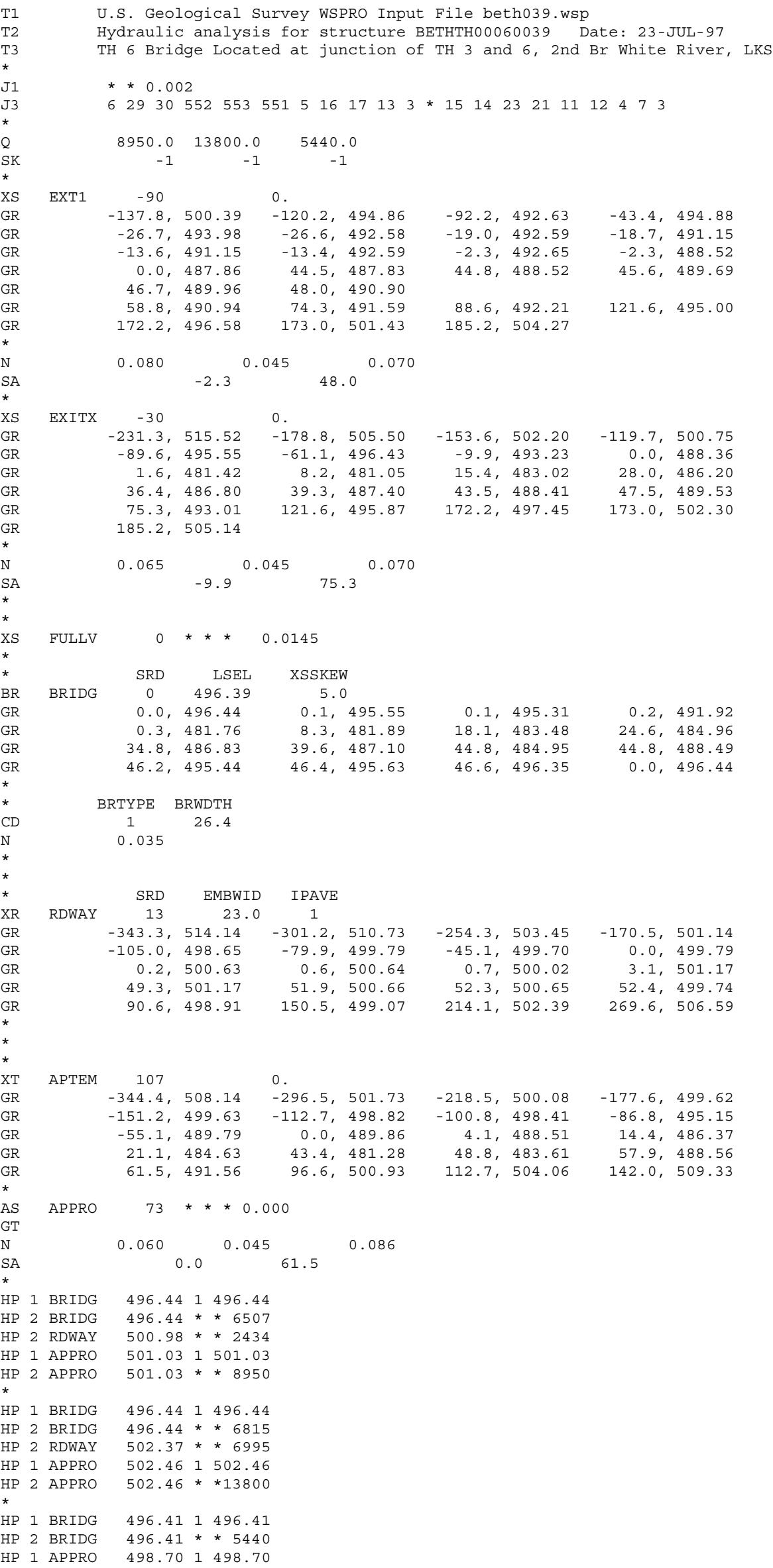




\section{APPENDIX B: \\ WSPRO OUTPUT FILE}




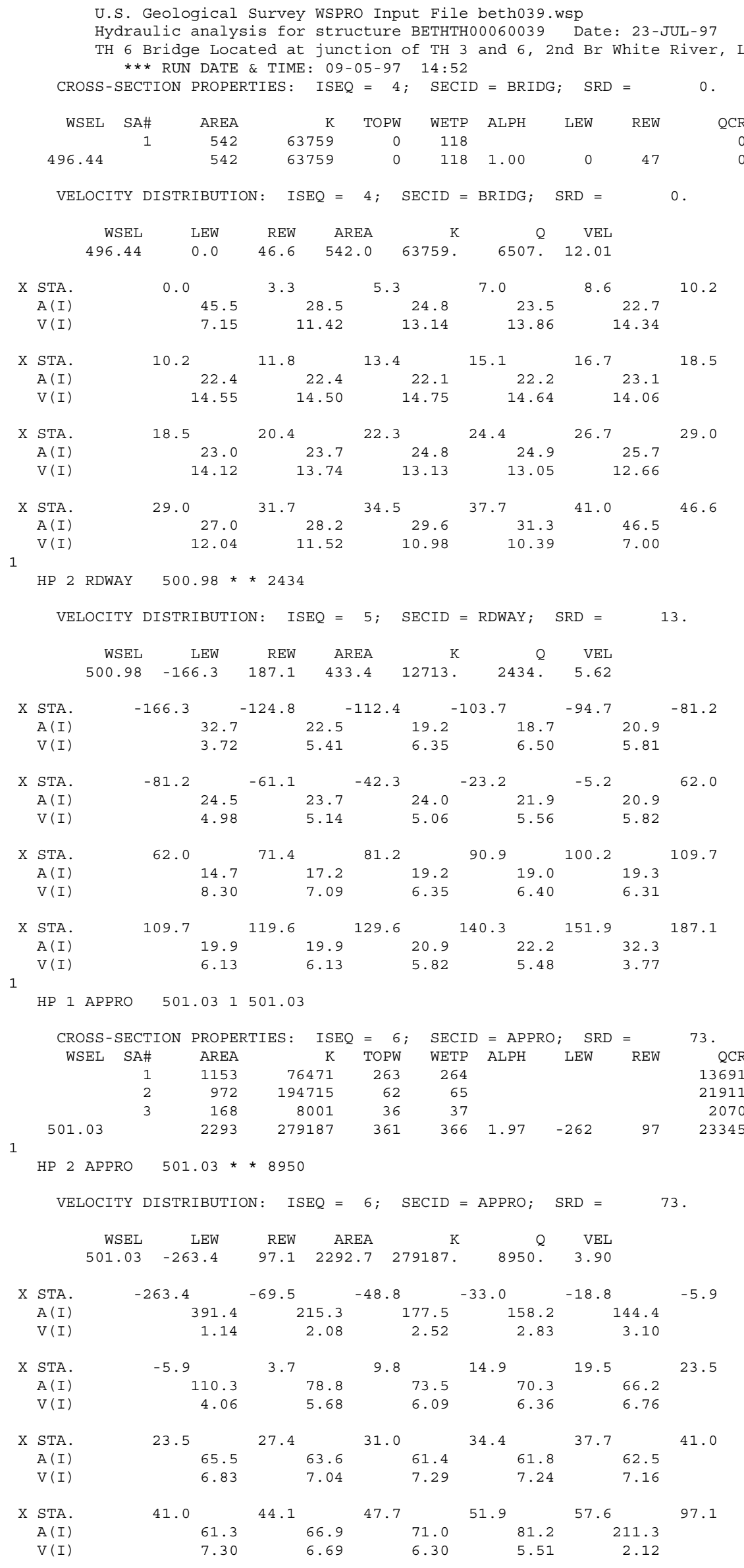


WSPRO OUTPUT FILE (continued)

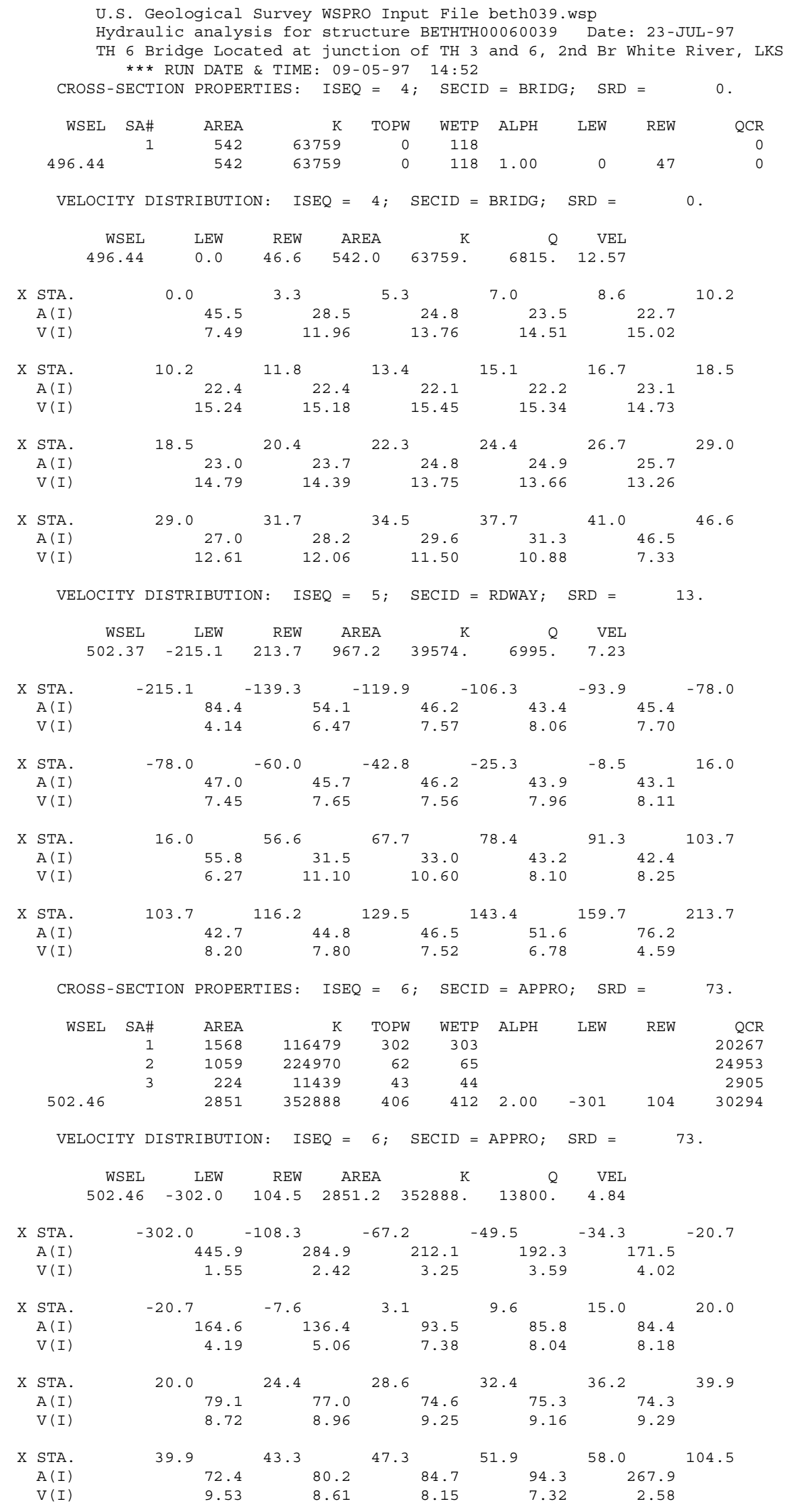


WSPRO OUTPUT FILE (continued)

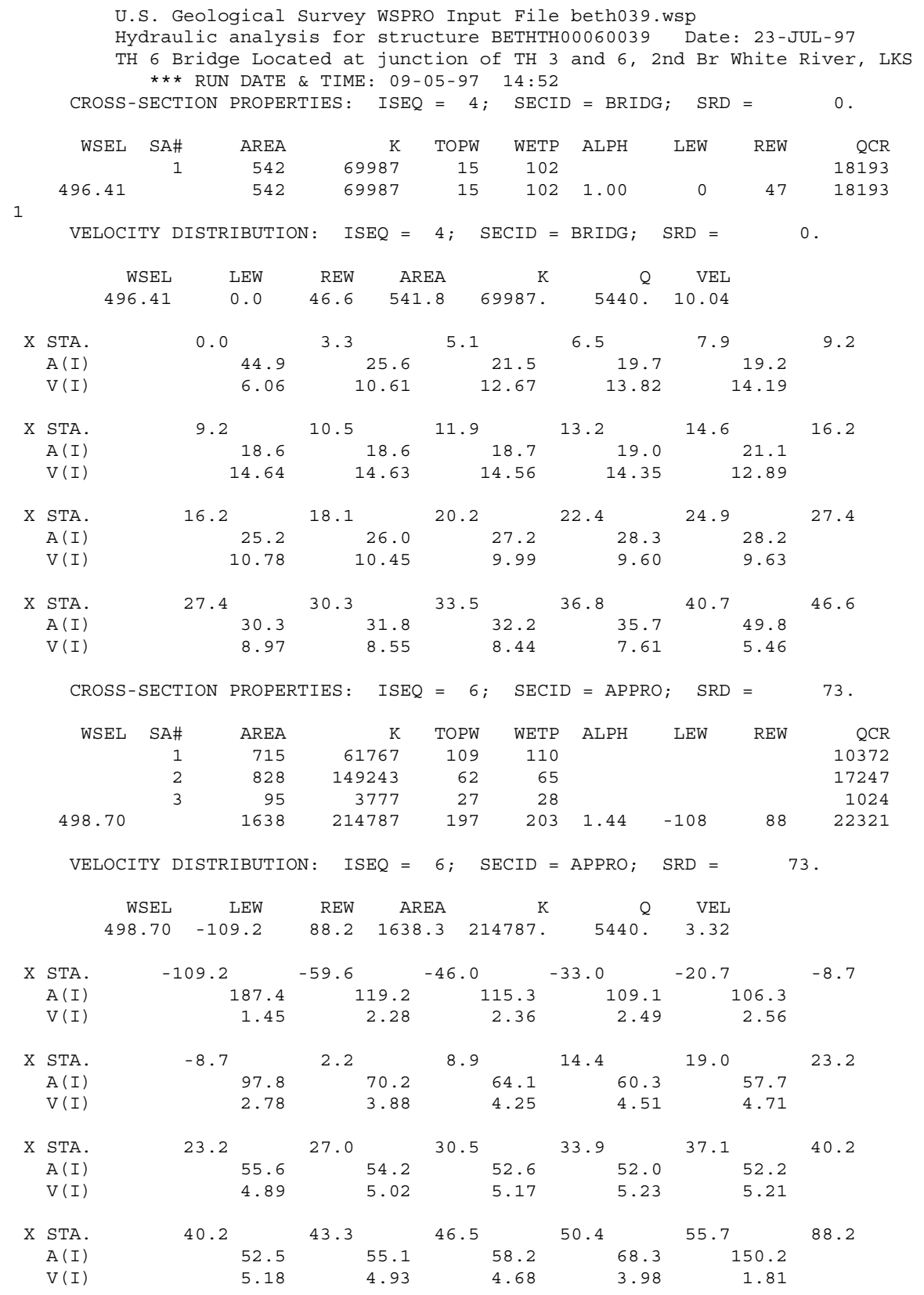


WSPRO OUTPUT FILE (continued)

\author{
U.S. Geological Survey WSPRO Input File beth039.wsp \\ Hydraulic analysis for structure BETHTH00060039 Date: 23-JUL-97 \\ $\mathrm{TH} 6$ Bridge Located at junction of $\mathrm{TH} 3$ and 6 , 2nd $\mathrm{Br}$ White River, LKS \\ *** RUN DATE \& TIME: 09-05-97 14:52 \\ $==010$ WSI BELOW YMIN AT SECID "EXT1 ": USED WSI = CRWS. \\ YMIN, WSI, CRWS $=487.8 \quad * * * \star * * * * \quad 496.81$

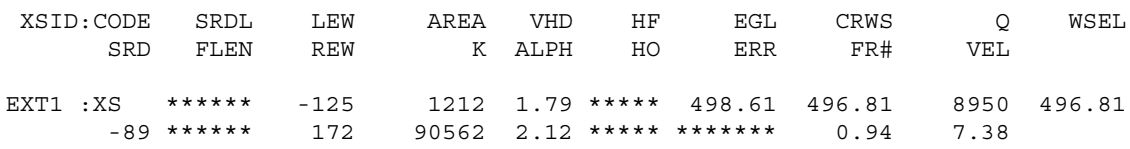 \\ $==135$ CONVEYANCE RATIO OUTSIDE OF RECOMMENDED LIMITS. \\ "EXITX" KRATIO $=1.57$

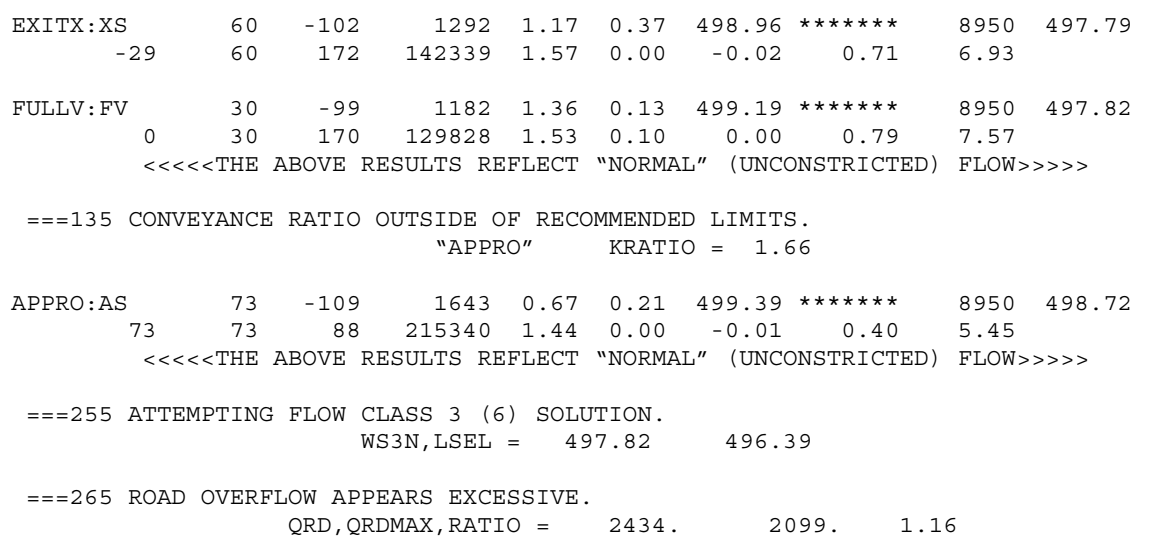

$\ll<<$ RESULTS REFLECTING THE CONSTRICTED FLOW FOLLOW $>>>>>$

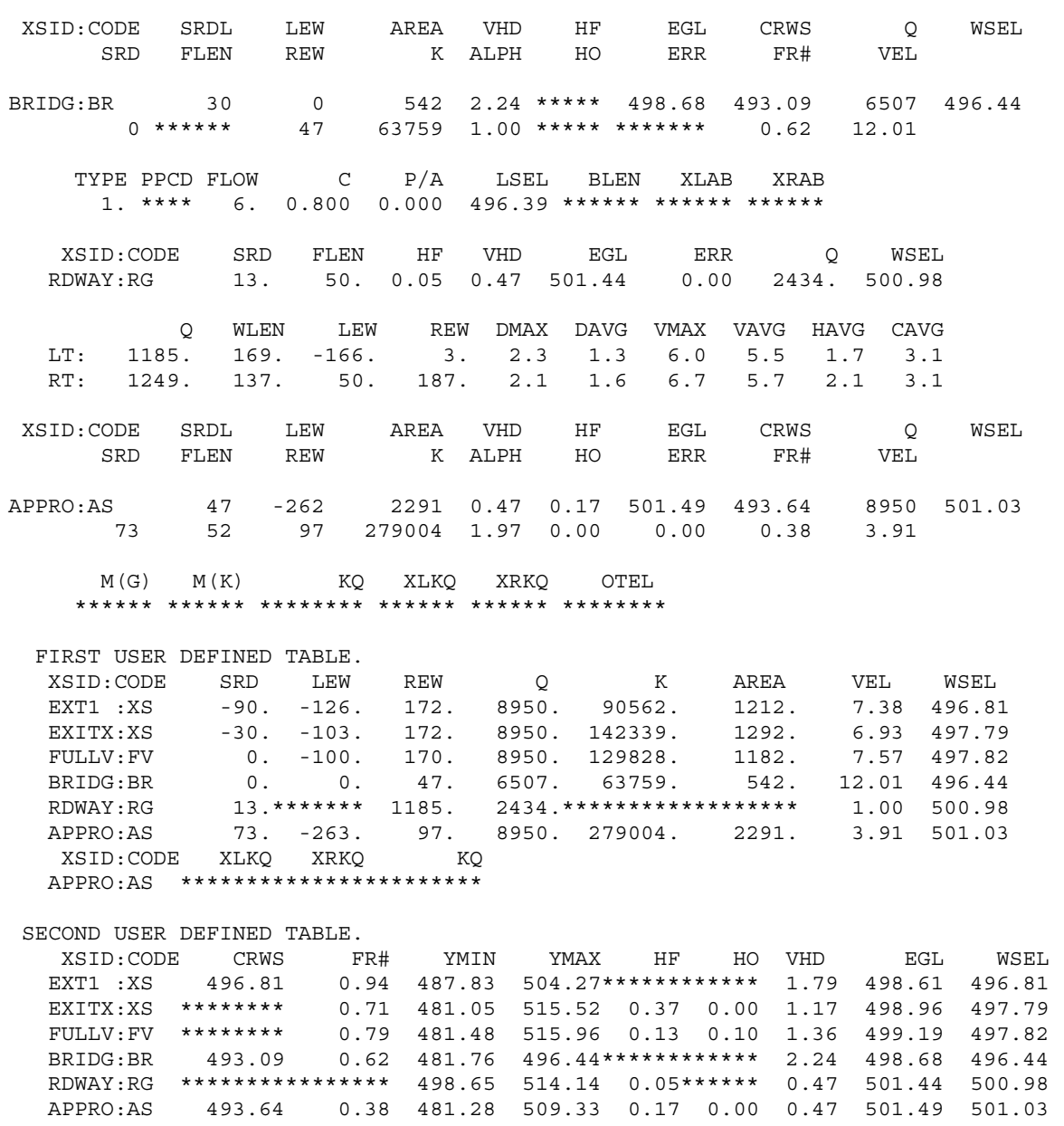




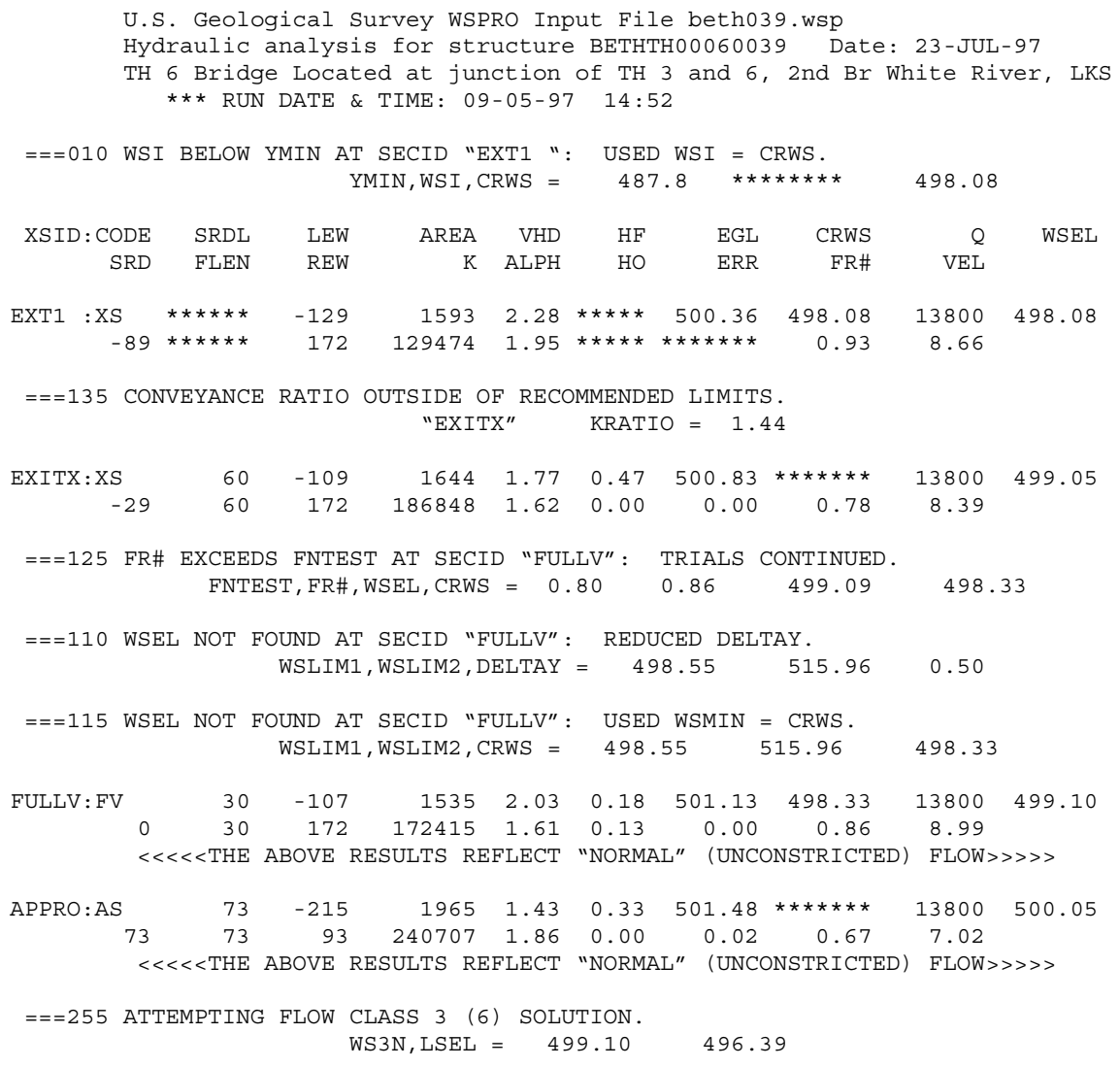


WSPRO OUTPUT FILE (continued)

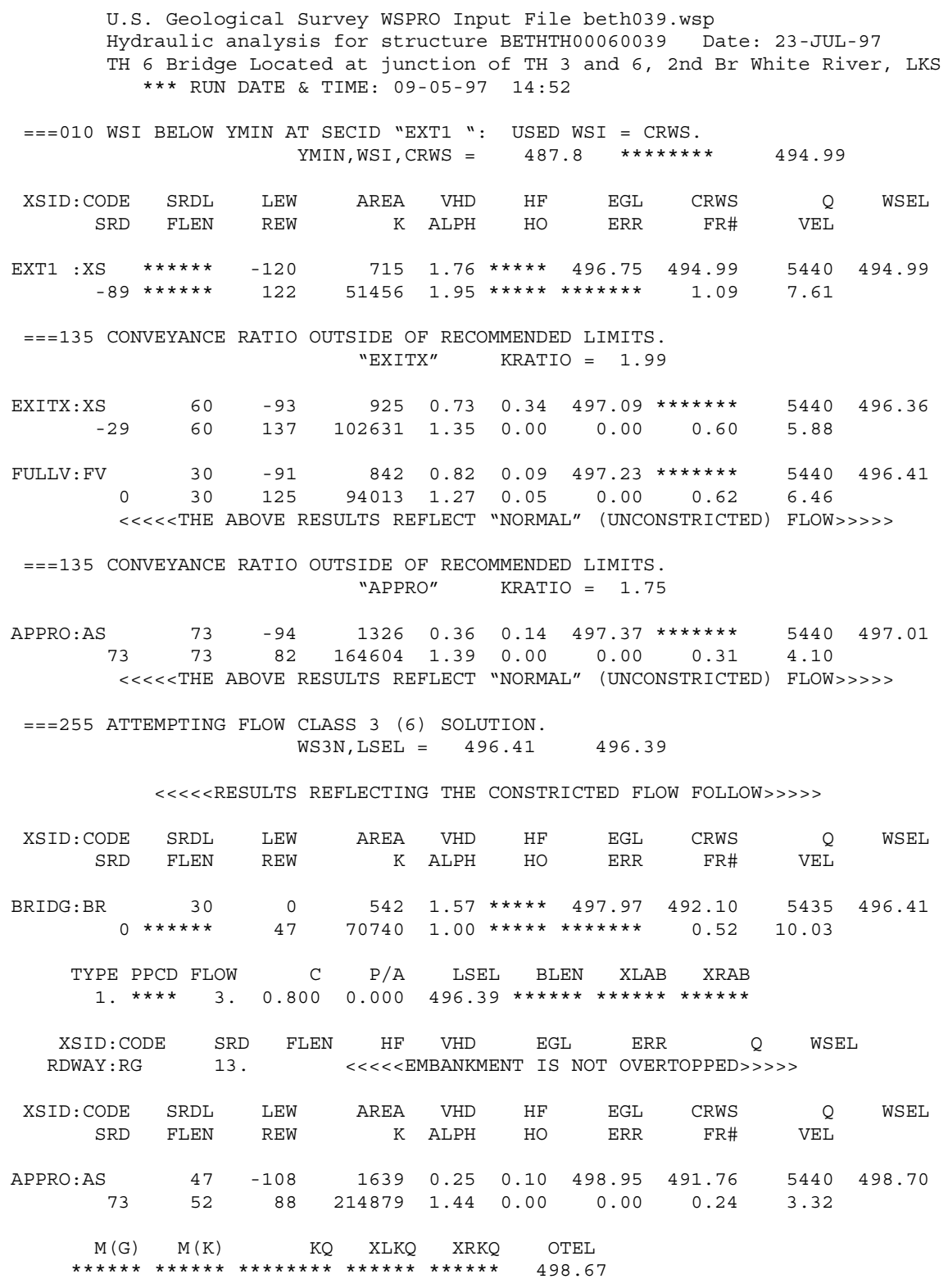

FIRST USER DEFINED TABLE.

\begin{tabular}{|c|c|c|c|c|c|c|c|c|}
\hline XSID : CODE & SRD & LEW & REW & 0 & $\mathrm{~K}$ & AREA & VEL & WSEL \\
\hline EXT1 :XS & -90 & -121. & 122. & 5440. & 51456. & 715. & 7.61 & 494.99 \\
\hline EXITX:XS & -30 & -94 & 137. & 5440. & 102631. & 925. & 5.88 & 496.36 \\
\hline FULLV : FV & 0 & -92 . & 125. & 5440. & 94013 & 842 . & 6.46 & 496.41 \\
\hline BRIDG : BR & 0. & 0 & 47. & 5435. & 70740 . & 542 . & 10.03 & 496.41 \\
\hline RDWAY : RG & \multicolumn{3}{|c|}{ 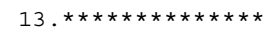 } & 0 . & 0 & 0 & \multicolumn{2}{|c|}{$1.00 * * * * * * * *$} \\
\hline APPRO : AS & 73. & -109. & 88 & 5440. & 214879 . & 1639. & 3.32 & 498.70 \\
\hline XSID : CODE & XLKQ & XRKQ & & & & & & \\
\hline
\end{tabular}

SECOND USER DEFINED TABLE.

$\begin{array}{lcrrrrrrrr}\text { XSID : CODE } & \text { CRWS } & \text { FR\# } & \text { YMIN } & \text { YMAX } & \text { HF } & \text { HO } & \text { VHD } & \text { EGL } & \text { WSEL } \\ \text { EXT1 : :XS } & 494.99 & 1.09 & 487.83 & 504.27 * * * * * * * * * * & 1.76 & 496.75 & 494.99 \\ \text { EXITX:XS } & * * * * * * * * & 0.60 & 481.05 & 515.52 & 0.34 & 0.00 & 0.73 & 497.09 & 496.36 \\ \text { FULLV:FV } & * * * * * * * * & 0.62 & 481.48 & 515.96 & 0.09 & 0.05 & 0.82 & 497.23 & 496.41 \\ \text { BRIDG:BR } & 492.10 & 0.52 & 481.76 & 496.44 * * * * * * * * * * * & 1.57 & 497.97 & 496.41 \\ \text { RDWAY: RG } & * * * * * * * * * * * * * * * * & 498.65 & 514.14 * * * * * * * * * * * * & 0.25 & 498.92 * * * * * * * \\ \text { APPRO:AS } & 491.76 & 0.24 & 481.28 & 509.33 & 0.10 & 0.00 & 0.25 & 498.95 & 498.70\end{array}$




\section{APPENDIX C:}

\section{BED-MATERIAL PARTICLE-SIZE DISTRIBUTION}




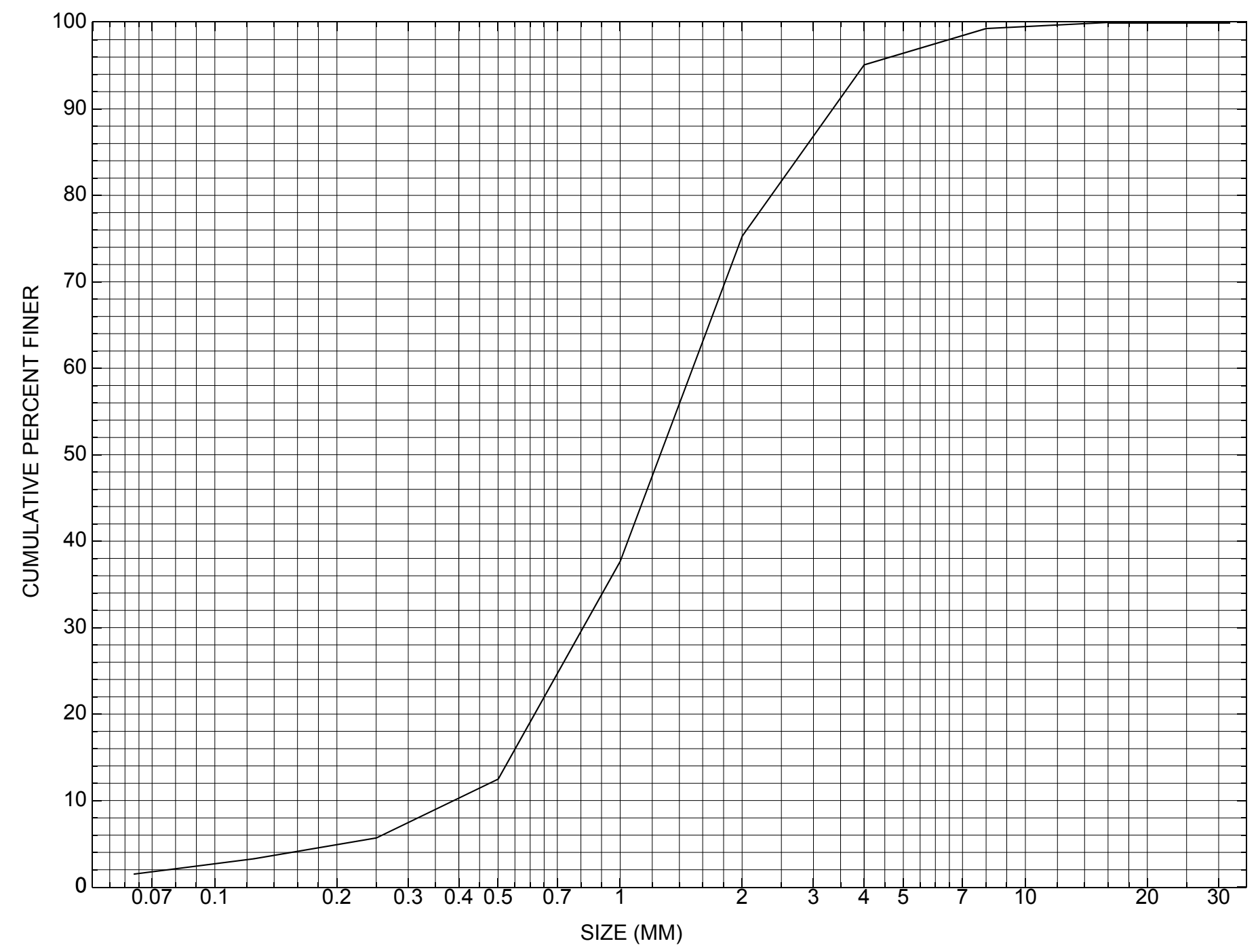

Appendix C. Bed material particle-size distribution for sediment sample from the channel approach of structure BETHTH00060039, in Bethel, Vermont. 


\section{APPENDIX D: \\ HISTORICAL DATA FORM}




\section{Structure Number BETHTH00060039}

\section{General Location Descriptive}

Data collected by (First Initial, Full last name) $\mathbf{E}$. BOEHMLER

Date $(M M / D D / Y Y) \_\mathbf{0 8} / \underline{\mathbf{2 4}} / \underline{\mathbf{9 4}}$

Highway District Number (I - 2; nn) $\mathbf{0 4}$

Town (FIPS place code; I - 4; nnnnn)

Waterway (I - 6) Second Branch of the White River

Route Number TH006

Topographic Map South Royalton

Latitude (I - 16; nnnn.n) $\mathbf{4 3 5 2 3}$
County (FIPS county code; I - 3; nnn)

Mile marker (I - 11; nnn.nnn) $\mathbf{0 0 0 0 0}$

Road Name (I - 7): -

Vicinity (I - 9) At jet with TH 3 and TH 6

Hydrologic Unit Code: $\mathbf{0 1 0 8 0 1 0 5}$

Longitude (i - 17; nnnnn.n) $\mathbf{7 2 3 5 3}$

\section{Select Federal Inventory Codes}

FHWA Structure Number (I - 8) 10140400391404

Maintenance responsibility $(I-21 ; n n) \quad \mathbf{0 3} \quad$ Maximum span length (I - 48; nnnn) $\underline{\mathbf{0 0 4 9}}$

Year built (I - 27; YYYY) 1938

Structure length (I - 49; nnnnnn) $\underline{\mathbf{0 0 0 0 5 2}}$

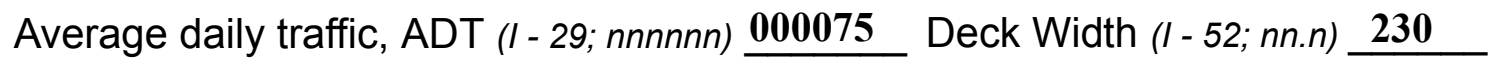

Year of ADT (I - 30; YY) $\underline{91}$

Channel \& Protection $(I-61 ; n) \underline{6}$

Opening skew to Roadway $(I-34 ; n n) \quad \mathbf{0 0}$

Waterway adequacy $(I-71 ; n)$

Operational status $(I-41 ; X)$ A

Underwater Inspection Frequency (I - 92B; XYY) Y48

Structure type (I - 43; nnn) $\mathbf{3 0 2}$

Year Reconstructed (I - 106) $\mathbf{0 0 0 0}$

Approach span structure type (I - 44; nnn) $\mathbf{0 0 0}$ Clear span (nnn.n ft) _ _

Number of spans (I - 45; nnn) $\mathbf{0 0 1}$

Vertical clearance from streambed (nnn.n ft) $\underline{\mathbf{0 1 2 . 5}}$

Number of approach spans (I - 46; nnnn) $\mathbf{0 0 0 0}$

Waterway of full opening $\left(n n n . n \mathrm{ft}^{2}\right)$

Comments:

Underwater inspection report of 7/16/92 indicates that the bridge is a steel beam type bridge. Maximum water depths reach $7 \mathrm{ft}$ at this site. The bridge is located about $100 \mathrm{ft}$ upstream of a dam. Heavy concrete spalling was reported at the ends of both abutments and wingwalls with some exposed rebar. Undermining and settlement were not apparent. Minor silt channel bars are noted. Scour and embankment erosion were not addressed on the report. The channel makes a sharp bend into the bridge crossing. There was no riprap noted. The roadway is paved. 


\section{Bridge Hydrologic Data}

Is there hydrologic data available? $\underline{\mathbf{N}}$ if No, type ctrl- $n$ VTAOT Drainage area $\left(\mathrm{mi}^{2}\right)$ : -

Terrain character:

Stream character \& type: -

Streambed material: Silt, sand, and some small stones

Discharge Data (cfs): $\quad \mathrm{Q}_{2.33}-$

$$
\mathrm{Q}_{50}-
$$

Record flood date (MM /DD/YY): - $/$ - $/$ -

$\begin{array}{ll}Q_{10} \_- & Q_{25}- \\ Q_{100 \_-} & Q_{500-}-\end{array}$

Water surface elevation (ft): -

Estimated Discharge (cfs): Velocity at $\mathrm{Q}-$ (ft/s): -

Ice conditions (Heavy, Moderate, Light) : -

Debris (Heavy, Moderate, Light):

The stage increases to maximum highwater elevation (Rapidly, Not rapidly):

The stream response is (Flashy, Not flashy):

Describe any significant site conditions upstream or downstream that may influence the stream's stage: There is a dam located approximately $100 \mathrm{ft}$ downstream from this site.

Watershed storage area (in percent): - _ \%

The watershed storage area is: - (1-mainly at the headwaters; 2- uniformly distributed; 3-immediatly upstream oi the site)

Water Surface Elevation Estimates for Existing Structure:

\begin{tabular}{|l|l|l|l|l|l|}
\hline Peak discharge frequency & $Q_{2.33}$ & $Q_{10}$ & $Q_{25}$ & $Q_{50}$ & $Q_{100}$ \\
Water surface elevation (ft)) & - & - & - & - & - \\
Velocity (ft/sec) & - & - & - & - & - \\
\hline
\end{tabular}

Long term stream bed changes: -

Is the roadway overtopped below the $\mathrm{Q}_{100}$ ? (Yes, No, Unknown): $\mathbf{U} \quad$ Frequency: -

Relief Elevation (ft):

Discharge over roadway at $\mathrm{Q}_{100}\left(\mathrm{ft}^{3} / \mathrm{sec}\right)$ :

Are there other structures nearby? (Yes, No, Unknown): $\underline{\mathbf{U}}$ Upstream distance (miles): Town: If No or Unknown, type ctrl-n os Highway No. : Structure No. : Year Built:

Clear span (ft): Clear Height (ft): Full Waterway $\left(f^{2}\right)$ : 
Downstream distance (miles): Town: Year Built:

Highway No. : Structure No. : Structure Type:

Clear span (ft): Clear Height $(f t)$ : Full Waterway $\left(f^{2}\right)$ : -

Comments:

\section{USGS Watershed Data}

Watershed Hydrographic Data

Drainage area $(D A) \underline{64.35} \mathrm{mi}^{2}$

Watershed storage (ST)

Bridge site elevation 520 0.7 $\mathrm{mi}^{2}$ Lake/pond/swamp area 0.47 $\mathrm{mi}^{2}$ Main channel length 20.78 $\mathrm{ft}$ $\%$ $10 \%$ channel length elevation $\mathbf{5 5 0}$ mi

Headwater elevation 1840 $\mathrm{ft}$

Main channel slope $(S)$ 10.91 $\mathrm{ft} / \mathrm{mi}$

Watershed Precipitation Data

Average site precipitation in Average headwater precipitation in

Maximum 2yr-24hr precipitation event $(124,2)$ in

Average seasonal snowfall (Sn) $\mathrm{ft}$ 


\section{Bridge Plan Data}

Are plans available? $\mathbf{N} \quad$ If no, type ctrl-n pl Date issued for construction (MM / YYYY):

Project Number

Minimum channel bed elevation:

Low superstructure elevation: USLAB DSLAB USRAB DSRAB Benchmark location description:

There is no benchmark information available.

Reference Point (MSL, Arbitrary, Other): -

Datum (NAD27, NAD83, Other):

Foundation Type: 4

If 1: Footing Thickness

If 2: Pile Type:

If 3: Footing bottom elevation:

Is boring information available? $\mathbf{N}$

Foundation Material Type: $\mathbf{3}$

(1-Spreadfooting; 2-Pile; 3- Gravity; 4-Unknown)

Footing bottom elevation: -

Briefly describe material at foundation bottom elevation or around piles:

There is no foundation material information available.

Comments:

There are no bridge plans available. 


\section{Cross-sectional Data}

Is cross-sectional data available? Yes If no, type ctrl-n xs

Source (FEMA, VTAOT, Other)? FEMA

Comments: The elevation and station measurements are in $\mathrm{ft}$.

\begin{tabular}{|l|l|l|l|l|l|l|l|l|l|l|l|}
\hline Station & $\mathbf{2 4 5}$ & $\mathbf{2 6 1}$ & $\mathbf{2 7 8}$ & $\mathbf{2 9 6}$ & - & - & - & - & - & - & - \\
\hline Feature & LAB & - & - & RAB & - & - & - & - & - & - & - \\
\hline $\begin{array}{l}\text { Low cord } \\
\text { elevation }\end{array}$ & $\mathbf{5 4 0}$ & $\mathbf{5 4 0}$ & $\mathbf{5 4 0}$ & $\mathbf{5 4 0}$ & - & - & - & - & - & - & - \\
\hline $\begin{array}{l}\text { Bed } \\
\text { elevation }\end{array}$ & $\mathbf{5 2 6 . 7}$ & $\mathbf{5 2 7 . 4}$ & $\mathbf{5 2 5}$ & $\mathbf{5 2 7 . 3}$ & - & - & - & - & - & - & - \\
\hline $\begin{array}{l}\text { Low cord to } \\
\text { bed length }\end{array}$ & $\mathbf{1 3 . 3}$ & $\mathbf{1 2 . 6}$ & $\mathbf{1 5}$ & $\mathbf{1 2 . 7}$ & - & - & - & - & - & - & - \\
\hline Station & - & - & - & - & - & - & - & - & - & - & - \\
\hline Feature & - & - & - & - & - & - & - & - & - & - & - \\
\hline $\begin{array}{l}\text { Low cord } \\
\text { elevation }\end{array}$ & - & - & - & - & - & - & - & - & - & - & - \\
\hline $\begin{array}{l}\text { Bed } \\
\text { elevation }\end{array}$ & - & - & - & - & - & - & - & - & - & - & - \\
\hline $\begin{array}{l}\text { Low cord to } \\
\text { bed length }\end{array}$ & - & - & - & - & - & - & - & - & - & - & - \\
\hline
\end{tabular}

Source (FEMA, VTAOT, Other)?

Comments: -

\begin{tabular}{|l|l|l|l|l|l|l|l|l|l|l|l|}
\hline Station & - & - & - & - & - & - & - & - & - & - & - \\
\hline Feature & - & - & - & - & - & - & - & - & - & - & - \\
\hline $\begin{array}{l}\text { Low cord } \\
\text { elevation }\end{array}$ & - & - & - & - & - & - & - & - & - & - & - \\
\hline $\begin{array}{l}\text { Bed } \\
\text { elevation }\end{array}$ & - & - & - & - & - & - & - & - & - & - & - \\
\hline $\begin{array}{l}\text { Low cord to } \\
\text { bed length }\end{array}$ & - & - & - & - & - & - & - & - & - & - & - \\
\hline Station & - & - & - & - & - & - & - & - & - & - & - \\
\hline Feature & - & - & - & - & - & - & - & - & - & - & - \\
\hline $\begin{array}{l}\text { Low cord } \\
\text { elevation }\end{array}$ & - & - & - & - & - & - & - & - & - & - & - \\
\hline $\begin{array}{l}\text { Bed } \\
\text { elevation }\end{array}$ & - & - & - & - & - & - & - & - & - & - & - \\
\hline $\begin{array}{l}\text { Low cord to } \\
\text { bed length }\end{array}$ & - & - & - & - & - & - & - & - & - & - & - \\
\hline
\end{tabular}




\section{APPENDIX E: \\ LEVEL I DATA FORM}


U. S. Geological Survey

Bridge Field Data Collection and Processing Form

Qa/Qc Check by: JRD

Date: $05 / 29 / 97$

\section{Structure Number}

ВETHTH00060039

\section{A. General Location Descriptive}

1. Data collected by (First Initial, Full last name) $\mathbf{J}$. DEGNAN

2. Highway District Number 04

County Windsor (027)

Waterway (I - 6) Second Branch of the White River

Route Number $\mathbf{\text { TH006 }}$

3. Descriptive comments:

The structure is located at the junction of TH 3 and TH 6.
Mile marker $\mathbf{0}$

Date $(M M / D D / Y Y) \mathbf{0 7} / \underline{11 / 1996}$
Town Bethel (05800)

Road Name -

Hydrologic Unit Code: $\mathbf{0 1 0 8 0 1 0 5}$

\section{B. Bridge Deck Observations}
4. Surface cover... LBUS 5
RBUS 5
LBDS 5
RBDS 5
Overall 5

(2b us, ds,lb,rb: 1- Urban; 2- Suburban; 3- Row crops; 4- Pasture; 5- Shrub- and brushland; 6- Forest; 7- Wetland)
5. Ambient water surface... US 1
UB 1
DS 1
(1- pool; 2- riffle)

6. Bridge structure type 1 (1- single span; 2- multiple span; 3- single arch; 4- multiple arch; 5-cylindrical culvert; 6- box culvert; or 7- other)
7. Bridge length $\mathbf{4 9 . 0}$
(feet)
Span length $\underline{\mathbf{5 2 . 0}}$
(feet)
Bridge width $\underline{\mathbf{2 3 . 0}}$ (feet)

\section{Road approach to bridge:}
8. LB 0
RB 0
( 0 even, 1- lower, 2- higher)
9. $\mathrm{LB}$
RB 1
(1- Paved, 2- Not paved)

10. Embankment slope (run / rise in feet / foot):

US left

US right

\begin{tabular}{|c|c|c|c|}
\hline \multicolumn{2}{|c|}{ Protection } & \multirow{2}{*}{ 13.Erosion } & \multirow{2}{*}{ 14.Severity } \\
\hline 11.Type & 12.Cond. & & \\
\hline 5 & & 2 & \\
\hline
\end{tabular}

LBUS

RBUS

RBDS

LBDS

\begin{tabular}{l|l|l|l|l}
5 & $\frac{1}{5}$ & $\frac{1}{5}$ & $\frac{1}{5}$ \\
\hline 5 & $\frac{1}{1}$ \\
\hline
\end{tabular}

$\frac{2}{0} \quad \frac{1}{-}$

Bank protection types: 0- none; 1- < 12 inches,

2- $<36$ inches; $3-<48$ inches;

4- < 60 inches; 5- wall / artificial levee

Bank protection conditions: 1- good; 2- slumped;

3- eroded; 4- failed

Erosion: 0 - none; 1- channel erosion; 2 -

road wash; 3- both; 4- other

Erosion Severity: 0 - none; 1- slight; 2- moderate; 3- severe

\section{Channel approach to bridge (BF):}

15. Angle of approach: $\mathbf{2 0}$

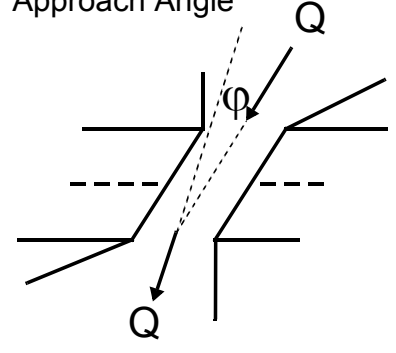

17. Channel impact zone 1 :

Where? RB (LB, RB)

Range? 0 feet US

Channel impact zone 2:

Where? LB (LB, RB)

Range? $\underline{\mathbf{1 0}}$ feet $\underline{\mathbf{U S}}$ (US, UB, DS) to $\underline{\mathbf{5 0}}$ feet $\underline{\mathbf{D S}}$

Impact Severity: 0- none to very slight; 1- Slight; 2- Moderate; 3- Severe
16. Bridge skew: 20 Bridge Skew Angle

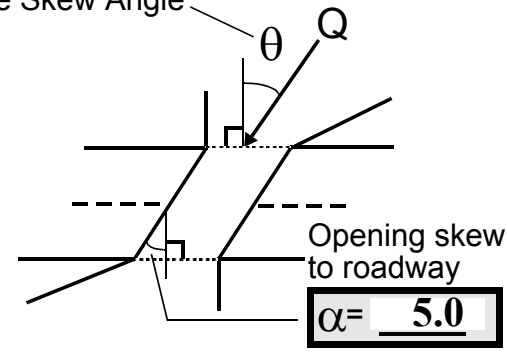

\section{Exist? $\mathbf{Y}(Y$ or $N)$}

Severity 2

US, UB, DS) to 100 feet $\underline{\mathbf{U S}}$

Exist? $\mathbf{Y}(\mathrm{Y}$ or $N)$

Severity 2 
18. Bridge Type: $\mathbf{1 b}$

1a- Vertical abutments with wingwalls

1 b- Vertical abutments without wingwalls

2- Vertical abutments and wingwalls, sloping embankment Wingwalls perpendicular to abut. face

3- Spill through abutments

4- Sloping embankment, vertical wingwalls and abutments

Wingwall angle less than $90^{\circ}$.

19. Bridge Deck Comments (surface cover variations, measured bridge and span lengths, bridge type variations, approach overflow width, etc.)

7. The measured bridge dimensions matched those from the VTAOT database.

11. Laid up stone walls continue on beyond where the concrete abutment side walls-protection ends.

\section{Upstream Channel Assessment}

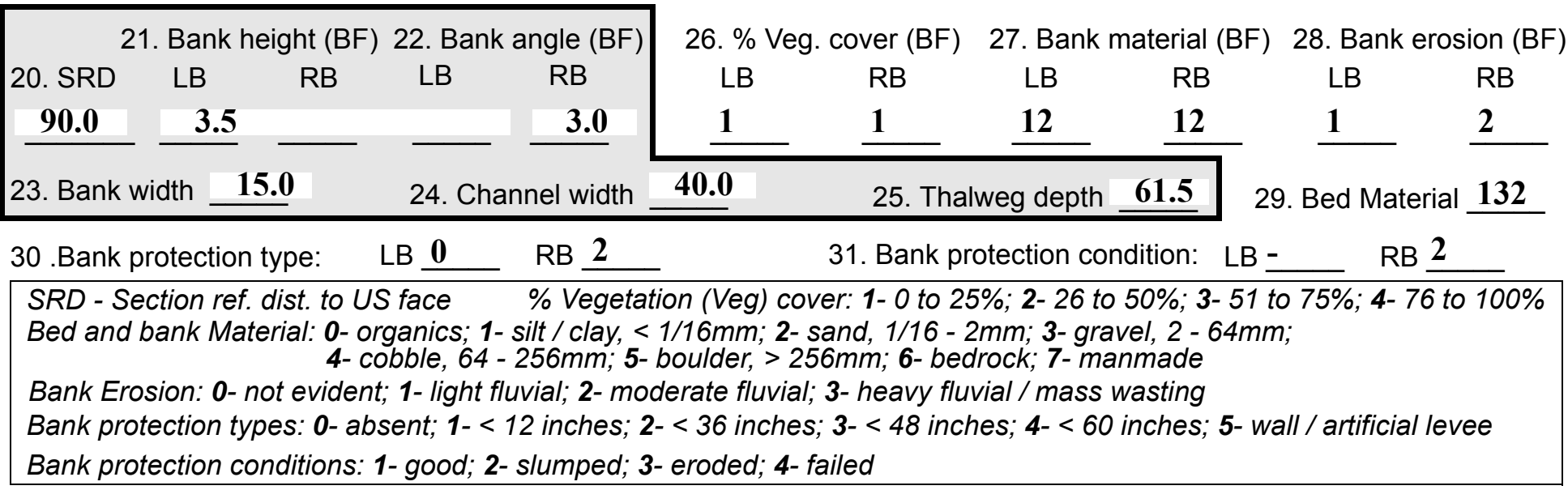

32. Comments (bank material variation, minor inflows, protection extent, etc.):

27. \& 29. Although the bed and bank material are composed primarily of silt and sand, there are a few small stones within the material.

30. The right bank protection extends from $50 \mathrm{ft}$ upstream to $0 \mathrm{ft}$ upstream. Much of the protection has slumped into the stream bed, with some along the steepened bank. 
36. Point bar extent: $\underline{\mathbf{3 0}}$ feet $\underline{\mathrm{US}}$ (US, UB) to $1 \mathbf{1 1 0}$ feet $\underline{\mathrm{US}}$ (US, UB, DS) positioned $\underline{\mathbf{0}} \%$ LB to 20 \%RB

37. Material: 1

38. Point or side bar comments (Circle Point or Side; Note additional bars, material variation, status, etc.):

This point bar is composed primarily of silt.

39. Is a cut-bank present? $\mathbf{Y}$ (Yor if $N$ type ctrl-n $c b)$

41. Mid-bank distance: $\mathbf{9 0}$

43. Bank damage: 1

42. Cut bank extent: 0
40. Where? $\underline{\mathbf{R B}}$ ( $L B$ or $R B)$ feet $\underline{\mathbf{U S}}$ (US, UB) to $\underline{\mathbf{2 0 0}}$ feet $\underline{\mathrm{US}}$ (US, UB, DS)

44. Cut bank comments (eg. additional cut banks, protection condition, etc.):

There is a steep slope along the entire length of the cut-bank.

\section{Is channel scour present? $\mathbf{Y}$ ( $Y$ or if $N$ type ctrl-n cs)}

47. Scour dimensions: Length $\mathbf{2 4 0}$

Width 25

Depth : $\underline{\mathbf{3}}$

48. Scour comments (eg. additional scour areas, local scouring process, etc.):

The scour hole extends from 120 upstream to $100 \mathrm{ft}$ downstream.

\section{Are there major confluences? $\mathbf{N}$}

( $Y$ or if $N$ type ctrl-n $m c)$

51. Confluence 1: Distance -

52. Enters on (LB or $R B$ )

Confluence 2: Distance -

Enters on (LB or $R B)$

54. Confluence comments (eg. confluence name):

There are no major confluences upstream at this site.

\section{Under Bridge Channel Assessment}

55. Channel restraint (BF)? LB 2 (1- natural bank; 2- abutment; 3- artificial levee)

56. Height (BF)
LB RB
$\mathbf{4 4 . 0}-$
58. Bank width (BF) -

$\begin{array}{cc}57 & \text { Angle (BF) } \\ \text { LB } & \text { RB } \\ 7.5 & \end{array}$

61. Material (BF)

LB RB

$\underline{2} \quad \underline{7}$

62. Erosion (BF)

LB RB

7

0

Bed and bank Material: 0- organics; 1- silt / clay, < 1/16mm; 2- sand, 1/16 - 2mm; 3- gravel, 2 - 64mm; 4- cobble, 64 - 256mm; 5- boulder, > 256mm; 6- bedrock; 7- manmade

Bank Erosion: 0- not evident; 1- light fluvial; 2- moderate fluvial; 3- heavy fluvial / mass wasting

64. Comments (bank material variation, minor inflows, protection extent, etc.):

132

The bed material is silt and sand with a few pieces of gravel. 
65. Debris and Ice Is there debris accumulation?

67. Debris Potential (1- Low; 2- Moderate; 3- High)

69. Is there evidence of ice build-up? $\underline{2}(Y$ or $N)$

70. Debris and Ice Comments:

2

67. Standing dead trees along the banks create a high debris potential.

68. The bridge constricts the channel raising the capture efficiency.

69. Spalling of the concrete abutment walls indicates the possibility of ice build-up. The spalling is severe from the water level up $2.0 \mathrm{ft}$.

\begin{tabular}{|l|c|c|c|c|c|c|c|c|}
\hline Abutments & $\begin{array}{c}\text { 71. Attack } \\
\angle \text { (BF) }\end{array}$ & $\begin{array}{c}\text { 72. Slope } \angle \\
\text { (Qmax) }\end{array}$ & $\begin{array}{c}\text { 73. Toe } \\
\text { loc. (BF) }\end{array}$ & $\begin{array}{c}\text { 74. Scour } \\
\text { Condition }\end{array}$ & $\begin{array}{c}75 . \text { Scour } \\
\text { depth }\end{array}$ & $\begin{array}{c}\text { 76. Exposure } \\
\text { depth }\end{array}$ & 77. Material & 78. Length \\
\hline LABUT & & $\mathbf{2 0}$ & $\mathbf{9 0}$ & $\mathbf{2}$ & $\mathbf{2}$ & $\mathbf{3}$ & $\mathbf{3}$ & $\mathbf{9 0 . 0}$ \\
\hline RABUT & $\mathbf{1}$ & $\mathbf{0}$ & $\mathbf{9 0}$ & & & $\mathbf{2}$ & $\mathbf{1}$ & $\mathbf{4 6 . 0}$ \\
\hline
\end{tabular}

Pushed: $L B$ or RB

Toe Location (Loc.): 0- even, 1- set back, 2- protrudes

Scour cond.: 0- not evident; 1- evident (comment); 2- footing exposed; 3-undermined footing; 4- piling exposed; 5- settled; 6- failed

Materials: 1- Concrete; 2- Stone masonry or drywall; 3- steel or metal; 4- wood

79. Abutment comments (eg. undermined penetration, unusual scour processes, debris, etc.):

3

0

1

76. The left abutment footing has $3.0 \mathrm{ft}$ of vertical exposure beginning at the upstream end, and extending to $8.0 \mathrm{ft}$ upstream of the downstream face. The total water depth is $7.0 \mathrm{ft}$ at the upstream end and $4.0 \mathrm{ft}$ at the downstream end of the left abutment. The depths along the right abutment also decrease with increasing distance downstream.

80. Wingwalls:

Exist? Material? Scour Scour Exposure $\begin{aligned} & 81 . \\ & \text { Angle? Length? }\end{aligned}$

USLWW: Condition? depth? depth?

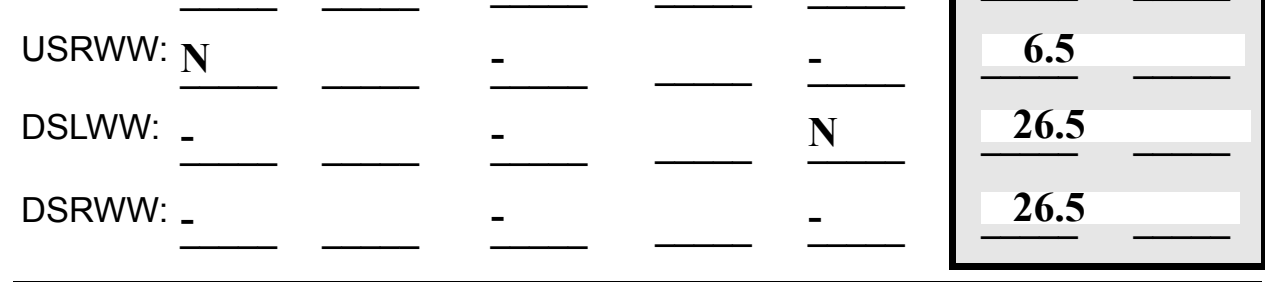

Wingwall materials: 1- Concrete; 2- Stone masonry or drywall; 3- steel or metal; 4- wood

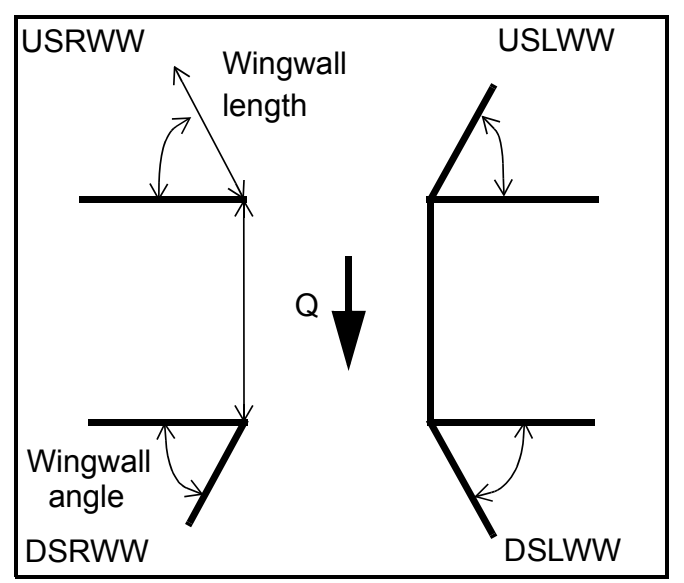

82. Bank / Bridge Protection:

\begin{tabular}{|l|l|l|l|l|l|l|l|l|}
\hline Location & USLWW & USRWW & LABUT & RABUT & LB & RB & DSLWW & DSRWW \\
\hline Type & - & - & $\mathbf{N}$ & - & - & - & - & - \\
\hline Condition & $\mathbf{N}$ & - & - & - & - & - & - & - \\
\hline Extent & - & - & - & $\mathbf{0}$ & $\mathbf{0}$ & $\mathbf{0}$ & $\mathbf{0}$ & $\mathbf{0}$ \\
\hline
\end{tabular}

Bank / Bridge protection types: 0- absent; 1- < 12 inches; 2- < 36 inches; 3- < 48 inches; 4- < 60 inches; 
83. Wingwall and protection comments (eg. undermined penetration, unusual scour processes, etc.):

-
-
-
-
0
-
-
0
-
-

\section{Piers:}

84. Are there piers? _ _ (Y or if $N$ type ctrl-n pr)

\begin{tabular}{|l|l|l|l|l|l|l|l|}
\hline \multirow{2}{*}{$\begin{array}{l}85 . \\
\text { Pier no. }\end{array}$} & \multicolumn{3}{|c|}{ width (w) feet } & \multicolumn{3}{c|}{ elevation (e) feet } \\
\cline { 2 - 9 } & w1 & w2 & w3 & e@w1 & e@w2 & e@w3 \\
\hline Pier 1 & - & - & - & - & - & - \\
\hline Pier 2 & - & - & - & - & - & - \\
\hline Pier 3 & - & - & - & - & - & - & - \\
\hline Pier 4 & - & - & - & - & - & w1 \\
\hline
\end{tabular}

\begin{tabular}{|l|l|l|l|l|}
\hline Level 1 Pier Descr. & 1 & \multicolumn{1}{|c|}{2} & 3 & \multicolumn{1}{|c|}{} \\
\hline 86. Location (BF) & & - & - & - \\
\hline 87. Type & & - & - & - \\
\hline 88. Material & & - & - & - \\
\hline 89. Shape & & - & - & - \\
\hline 90. Inclined? & & - & - & - \\
\hline 91. Attack $\angle$ (BF) & & - & - & - \\
\hline 92. Pushed & & - & - & - \\
\hline 93. Length (feet) & - & - & - & - \\
\hline 94. \# of piles & & - & - & - \\
\hline 95. Cross-members & & - & - & - \\
\hline 96. Scour Condition & & - & - & - \\
\hline 97. Scour depth & $\mathbf{N}$ & - & - & - \\
\hline 98. Exposure depth & - & - & - & - \\
\hline
\end{tabular}

LFP, LTB, LB, MCL, MCM, MCR, RB, RTB, RFP

1- Solid pier, 2- column, 3- bent

1-Wood; 2- concrete; 3- metal; 4- stone

1- Round; 2- Square; 3- Pointed

Y-yes; $N-$ no

$L B$ or $R B$

0- none; 1- laterals; 2- diagonals; 3- both

0- not evident; 1- evident (comment);

2- footing exposed; 3- piling exposed;

4- undermined footing; 5- settled; 6- failed 
99. Pier comments (eg. undermined penetration, protection and protection extent, unusual scour processes, etc.):

-

100.

\section{E. Downstream Channel Assessment}

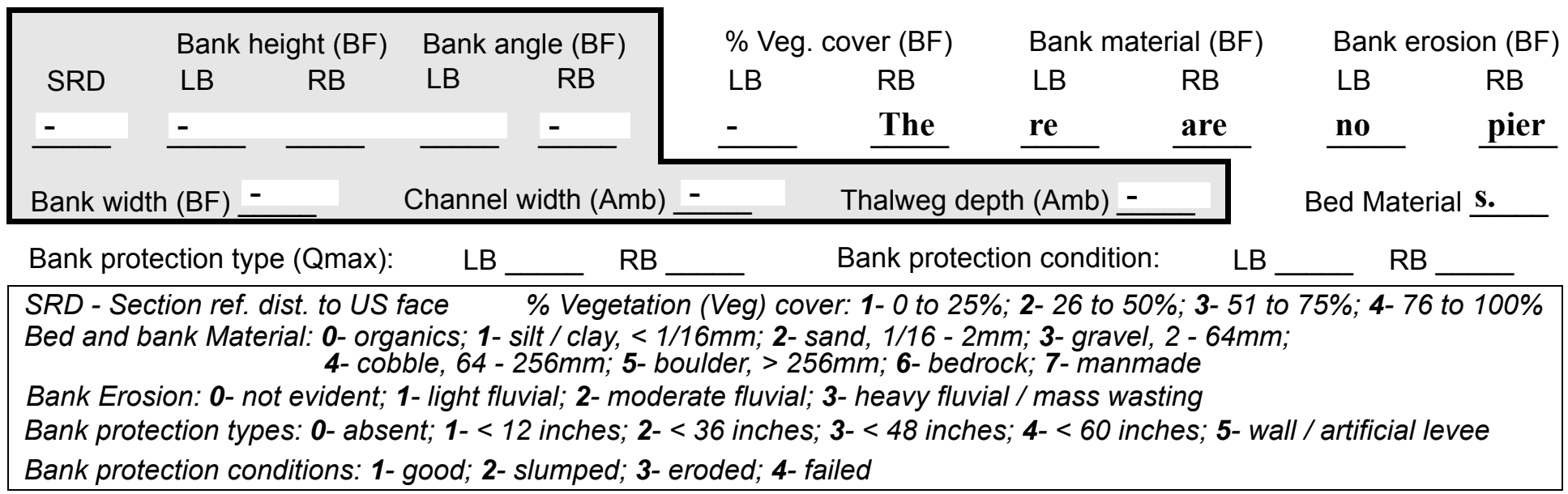

Comments (eg. bank material variation, minor inflows, protection extent, etc.):

2
2
132
132
1
0
142
2
0
2

101. Is a drop structure present? _ ( $Y$ or $N$, if $N$ type ctrl-n ds) 102. Distance: ___ feet

103. Drop: - feet 104. Structure material: Th (1- steel sheet pile; 2- wood pile; 3- concrete; 4- other)

105. Drop structure comments (eg. downstream scour depth):

e bed and bank material is silt and sand with a few pieces of gravel sized material.

The left bank protection extends from zero $\mathrm{ft}$ downstream to $60 \mathrm{ft}$ downstream. 
106. Point/Side bar present? ( $Y$ or N. if $N$ type ctrl-n pb)Mid-bar distance:

Mid-bar width:

Point bar extent: feet

(US, UB, DS) to feet (US, UB, DS) positioned $\%$ LB to $\% R B$

Material: $\mathbf{Y}$

Point or side bar comments (Circle Point or Side; yote additional bars, material variation, status, etc.):

3

There is a concrete dam $150 \mathrm{ft}$ downstream of the structure which raises the water surface elevation.

Is a cut-bank present? (Y or if $N$ type ctrl- $n$ cb) Where? (LB or $R B)$

Mid-bank distance:

Cut bank extent: $\underline{Y}$ feet $\underline{60}$ (US, UB, DS) to $\underline{40}$ feet $\underline{15}$ (US, UB, DS)

Bank damage: UB (1- eroded and/or creep; 2- slip failure; 3- block failure)

Cut bank comments (eg. additional cut banks, protection condition, etc.):

80

DS

40

100

Is channel scour present? 2 (Y or if $N$ type ctrl-n cs) Mid-scour distance: This

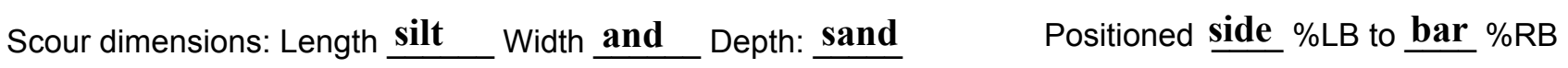

Scour comments (eg. additional scour areas, local scouring process, etc.):

extends from under the bridge to the dam downstream.

Are there major confluences? $\mathbf{Y}$ ( $Y$ or if $N$ type ctrl-n $m c)$

How many? $\underline{\mathbf{L B}}$

Confluence 1: Distance 60 Enters on $\underline{0} \quad(L B$ or $R B)$

Type $\underline{\text { DS }}$

(1- perennial; 2- ephemeral)

Confluence 2: Distance 90

Enters on $\underline{\text { DS }}(L B$ or $R B)$

Type 1 (1- perennial; 2- ephemeral)

Confluence comments (eg. confluence name):

The bank is over steepened with protection under water. The bank is silt above the protection. There is wood protruding out of the cut-bank in the last twenty ft. There is no stone protection found in this area of the cut-

\section{F. Geomorphic Channel Assessment}

107. Stage of reach evolution ba

1- Constructed

2- Stable

3- Aggraded

4- Degraded

5- Laterally unstable

6- Vertically and laterally unstable 
108. Evolution comments (Channel evolution not considering bridge effects; See HEC-20, Figure 1 for geomorphic descriptors):

nk.

$\mathbf{N}$

$-$

$-$

$-$

$-$

$-$

$-$

There is no channel scour present downstream at this site. 


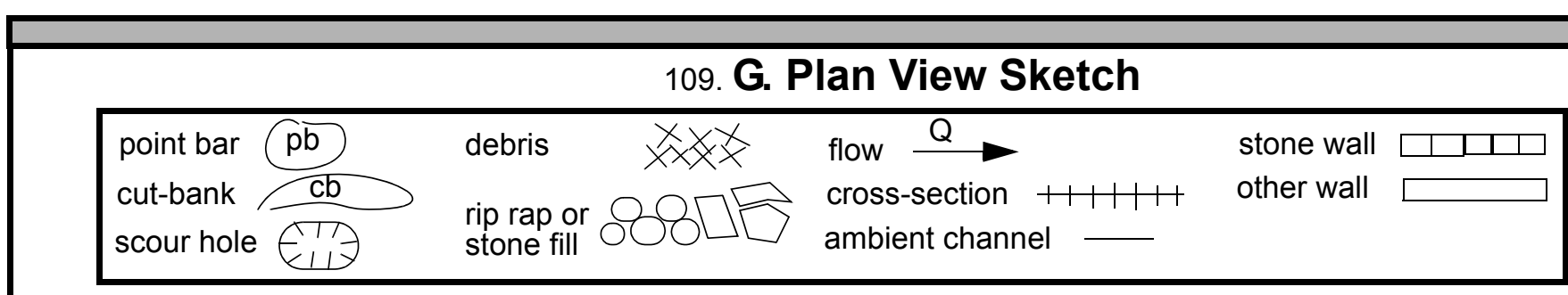


APPENDIX F:

SCOUR COMPUTATIONS 
SCOUR COMPUTATIONS

\begin{tabular}{|c|c|c|c|}
\hline Structure Number: BETHTH00060039 & & Town : & \\
\hline Road Number: $\quad$ TH 6 & & County: & WINDSOR \\
\hline 2ND BRANCH WHITE & RIVER & & \\
\hline Initials LKS & Checked: & EMB & \\
\hline Analysis of contraction scour, live & -bed or $\mathrm{cl}$ & lear wate & \\
\hline $\begin{array}{l}\text { Critical Velocity of Bed Material } \\
\mathrm{Vc}=11.21 * \mathrm{~V}^{\wedge} 0.1667 * \mathrm{D} 50^{\wedge} 0.33 \text { with SS }\end{array}$ & $\begin{array}{l}\text { converted } \\
=2.65\end{array}$ & to Engl: & sh units) \\
\hline (Richardson and Davis, 1995, p. 28, & eq. 16$)$ & & \\
\hline Approach section & & & \\
\hline Characteristic & $100 \mathrm{yr}$ & 500 yr & other $Q$ \\
\hline Total discharge, cfs & 8950 & 13800 & 5440 \\
\hline Main Channel Area, ft2 & 972 & 1059 & 828 \\
\hline Left overbank area, ft2 & 1153 & 1568 & 715 \\
\hline Right overbank area, ft2 & 168 & 224 & 95 \\
\hline Top width main channel, ft & 62 & 62 & 62 \\
\hline Top width L overbank, ft & 263 & 302 & 109 \\
\hline Top width $\mathrm{R}$ overbank, ft & 36 & 43 & 27 \\
\hline D50 of channel, ft & 0.004 & 0.004 & 0.004 \\
\hline D50 left overbank, ft & -- & -- & -- \\
\hline D50 right overbank, ft & -- & -- & -- \\
\hline y1, average depth, MC, ft & 15.7 & 17.1 & 13.4 \\
\hline Y1, average depth, LOB, ft & 4.4 & 5.2 & 6.6 \\
\hline Y1, average depth, ROB, ft & 4.7 & 5.2 & 3.5 \\
\hline Total conveyance, approach & 279187 & 352888 & 214787 \\
\hline Conveyance, main channel & 194715 & 224970 & 149243 \\
\hline Conveyance, LOB & 76471 & 116479 & 61767 \\
\hline Conveyance, ROB & 8001 & 11439 & 3777 \\
\hline Percent discrepancy, conveyance & 0.0000 & 0.0000 & 0.0000 \\
\hline Qm, discharge, MC, cfs & 6242.1 & 8797.7 & 3779.9 \\
\hline Q1, discharge, LOB, cfs & 2451.5 & 4555.0 & 1564.4 \\
\hline Qr, discharge, ROB, cfs & 256.5 & 447.3 & 95.7 \\
\hline Vm, mean velocity $\mathrm{MC}$, ft/s & 6.4 & 8.3 & 4.6 \\
\hline V1, mean velocity, LOB, ft/s & 2.1 & 2.9 & 2.2 \\
\hline Vr, mean velocity, ROB, ft/s & 1.5 & 2.0 & 1.0 \\
\hline Vc-m, crit. velocity, $\mathrm{MC}$, ft/s & 2.8 & 2.9 & 2.7 \\
\hline Vc-l, crit. velocity, LOB, ft/s & ERR & ERR & ERR \\
\hline Vc-r, crit. velocity, ROB, ft/s & ERR & ERR & ERR \\
\hline Results & & & \\
\hline Live-bed(1) or Clear-Water(0) Contr & action $\mathrm{Scc}$ & our? & \\
\hline Main Channel & 1 & 1 & 1 \\
\hline Left Overbank & $\mathrm{N} / \mathrm{A}$ & $\mathrm{N} / \mathrm{A}$ & $\mathrm{N} / \mathrm{A}$ \\
\hline Right Overbank & $\mathrm{N} / \mathrm{A}$ & $\mathrm{N} / \mathrm{A}$ & $\mathrm{N} / \mathrm{A}$ \\
\hline
\end{tabular}




\begin{tabular}{|c|c|c|c|c|c|c|}
\hline \multicolumn{7}{|c|}{ 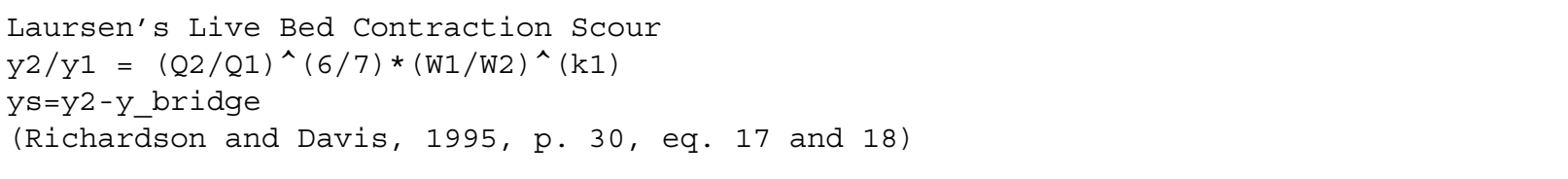 } \\
\hline & Approach & & & Bridge & & \\
\hline Characteristic & $100 \mathrm{yr}$ & $500 \mathrm{yr}$ & Other $Q$ & $100 \mathrm{yr}$ & $500 \mathrm{yr}$ & Other Q \\
\hline Q1, discharge, cfs & 8950 & 13800 & 5440 & 6507 & 6815 & 5440 \\
\hline Total conveyance & 279187 & 352888 & 214787 & 63759 & 63759 & 69987 \\
\hline Main channel conveyance & 194715 & 224970 & 149243 & 63759 & 63759 & 69987 \\
\hline Main channel discharge & 6242 & 8798 & 3780 & 6507 & 6815 & 5440 \\
\hline Area - main channel, ft2 & 972 & 1059 & 828 & 542 & 542 & 541.8 \\
\hline (W1) channel width, ft & 62 & 62 & 62 & 46.4 & 46.4 & 46.4 \\
\hline (Wp) cumulative pier width, ft & 0 & 0 & 0 & 0 & 0 & 0 \\
\hline W1, adjusted bottom width(ft) & 62 & 62 & 62 & 46.4 & 46.4 & 46.4 \\
\hline D50, ft & 0.004 & 0.004 & 0.004 & & & \\
\hline w, fall velocity, ft/s (p. 32) & 0.4965 & 0.4965 & 0.4965 & & & \\
\hline y, ave. depth flow, ft & 15.68 & 17.08 & 13.35 & 11.68 & 11.68 & 11.68 \\
\hline S1, slope EGL & 0.0027 & 0.0048 & 0.0019 & & & \\
\hline $\mathrm{P}$, wetted perimeter, $\mathrm{MC}$, ft & 65 & 65 & 65 & & & \\
\hline R, hydraulic Radius, ft & 14.954 & 16.292 & 12.738 & & & \\
\hline $\mathrm{V*}$, shear velocity, ft/s & 1.140 & 1.587 & 0.883 & & & \\
\hline $\mathrm{V} * / \mathrm{w}$ & 2.297 & 3.196 & 1.778 & & & \\
\hline $\begin{array}{l}\text { Bed transport coeff., k1, (0.59 if } \\
\text { k1 }\end{array}$ & $\begin{array}{l}\mathrm{V} * / \mathrm{w}<0.5 ; \\
0.69\end{array}$ & $\begin{array}{l}0.64 \text { if } \\
0.69\end{array}$ & $\begin{array}{l}.5<V^{*} / \mathrm{w}<2 ; \\
0.64\end{array}$ & 0.69 if & $\mathrm{V}^{*} / \mathrm{w}>2.0$ & $0 \mathrm{p} .33)$ \\
\hline $\mathrm{y}^{2}$, depth in contraction, ft & 19.84 & 16.76 & 21.96 & & & \\
\hline ys, scour depth, ft (y2-y_bridge) & 8.16 & 5.08 & 10.29 & & & \\
\hline
\end{tabular}


Pressure Flow Scour (contraction scour for orifice flow conditions)

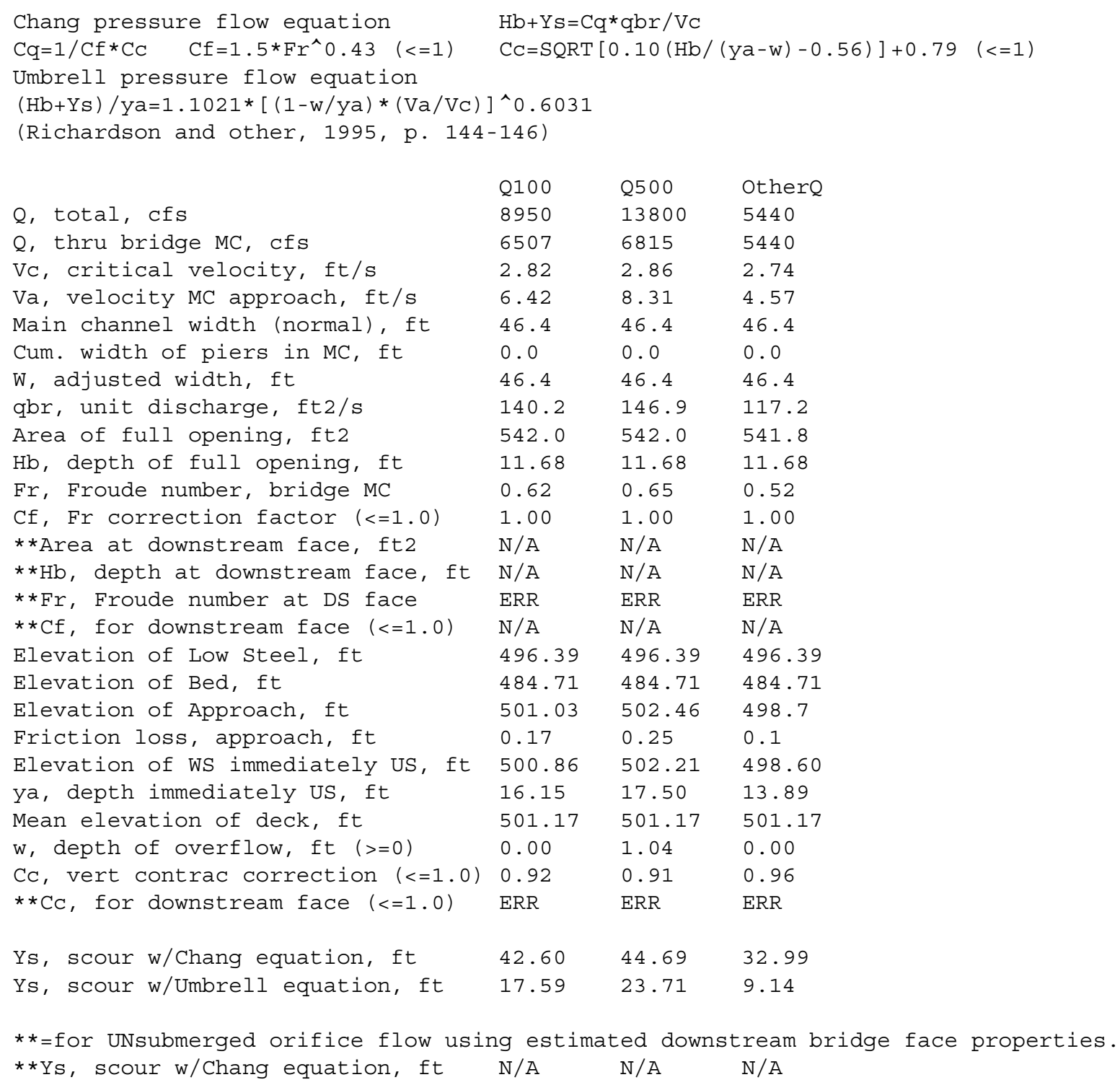




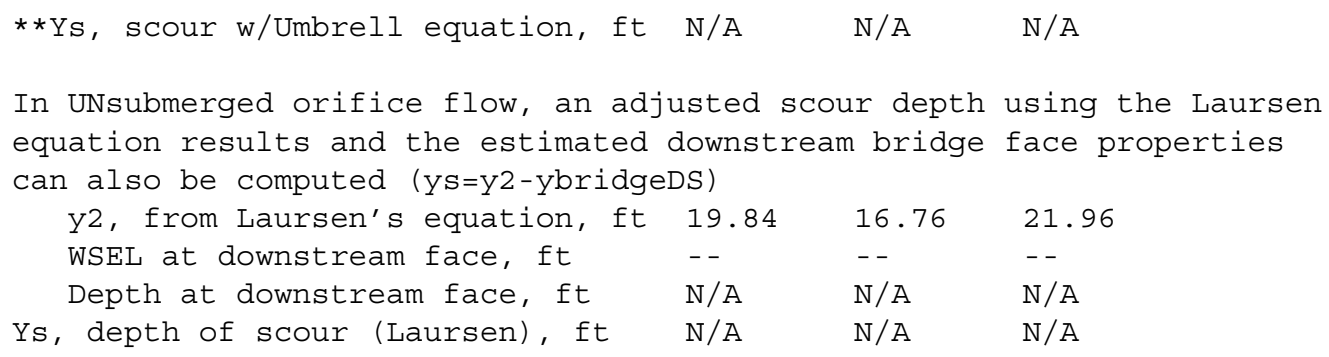

\section{Abutment Scour}

Froehlich's Abutment Scour

18.98

HIRE equation ( $a^{\prime} /$ ya $\left.>25\right)$

$\mathrm{ys}=4 * \mathrm{Fr}^{\wedge} 0.33 * \mathrm{Y} 1 * \mathrm{~K} / 0.55$

(Richardson and Davis, 1995, p. 49, eq. 29) 


\begin{tabular}{|c|c|c|c|c|c|c|}
\hline$a^{\prime}$ (abut length blocked, ft) & 263.6 & 302.2 & 109.4 & 50.5 & 57.9 & 41.6 \\
\hline y1 (depth $\mathrm{f} / \mathrm{p}$ flow, $\mathrm{ft}$ ) & 3.59 & 3.64 & 6.56 & 6.25 & 5.08 & 6.62 \\
\hline$a^{\prime} / y^{\prime}$ & 73.37 & 83.09 & 16.69 & 8.09 & 11.39 & 6.29 \\
\hline Skew correction (p. 49, fig. 16) & 1.01 & 1.01 & 1.01 & 0.98 & 0.98 & 0.98 \\
\hline Froude no. f/p flow & 0.18 & 0.23 & 0.15 & 0.25 & 0.30 & 0.20 \\
\hline Ys w/ corr. factor K1/0.55: & & & & & & \\
\hline vertical & 15.07 & 16.40 & ERR & ERR & ERR & ERR \\
\hline vertical w/ ww's & 12.36 & 13.45 & ERR & ERR & ERR & ERR \\
\hline spill-through & 8.29 & 9.02 & ERR & ERR & ERR & ERR \\
\hline Abutment riprap Sizing & & & & & & \\
\hline Isbash Relationship & & & & & & \\
\hline $\begin{array}{l}\mathrm{D} 50=\mathrm{Y}^{*} \mathrm{~K} * \mathrm{Fr} \mathrm{r}^{\wedge} 2 /(\mathrm{SS}-1) \text { and } \mathrm{D} 50=\mathrm{Y}^{*} \mathrm{~K} * \\
\text { (Richardson and Davis, 1995, p11 }\end{array}$ & $\begin{array}{l}\wedge 21 \wedge 0.1 \\
\text { eq. } 81,\end{array}$ & $(\mathrm{Ss}-1)$ & & & & \\
\hline Characteristic & Q100 & Q500 & Other $Q$ & Q100 & Q500 & Other $Q$ \\
\hline Fr, Froude Number & 0.62 & 0.65 & 0.52 & 0.62 & 0.65 & 0.52 \\
\hline$y$, depth of flow in bridge, ft & 11.68 & 11.68 & 11.68 & 11.68 & 11.68 & 11.68 \\
\hline Median stone Diameter for riprap & : left & utment & & right & abutment, & ft \\
\hline Fr<=0.8 (vertical abut.) & 2.78 & 3.05 & 1.95 & 2.78 & 3.05 & 1.95 \\
\hline Fr>0.8 (vertical abut.) & ERR & ERR & ERR & ERR & ERR & ERR \\
\hline
\end{tabular}

